\title{
Derbid Planthoppers (Hemiptera: Fulgoroidea: Derbidae) Associated with Coconut and Oil Palm in Brazil
}

\author{
M Dollet ${ }^{1,2}$ (D) EG Fidelis ${ }^{3}$, E Dos Passos ${ }^{4}, \mathrm{~F}$ Da Silva ${ }^{5}$, HP Aberlenc $^{6}$, DA Schurt ${ }^{7}$, B Bahder ${ }^{8}$, \\ LC DINIZ $^{4}$, CR BARTLETT ${ }^{9}$
}

${ }^{1}$ Cirad, Umr Ipme Cirad/Ird/UM, Campus International, de Baillarguet, Montpellier Cedex 5, France

${ }^{2}$ Embrapa Cenargen, Brasilia, DF, Brasil

${ }^{3}$ Embrapa Cerrados, Brasilia, DF, Brasil

${ }^{4}$ Embrapa Tabuleiros Costeiros, Aracaju, SE, Brasil

${ }^{5}$ Instituto Federal do Amapá, Macapá, AM, Brasil

${ }^{6}$ Cirad, Umr Bgpi, Montpellier, France

${ }^{7}$ Embrapa Roraima, Boa Vista, RR, Brasil

${ }^{8}$ Univ of Florida, Fort Lauderdale, FL, USA

${ }^{9}$ Univ of Delaware, Newark, DE, USA

\section{Keywords}

Fulgoromorpha, Auchenorrhyncha, Cenchreini, phytoplasmas, lethal yellowing type syndromes, vectors

\section{Correspondence \\ M Dollet, Embrapa Cenargen, Brasilia, DF, Brasil; dolletm.palm@gmail.com}

Edited by Takumasa Kondo - CORPOICA

Received 9 March 2020 and accepted 25 May 2020

Published online: 27 July 2020

(C) The Author(s) 2020

\begin{abstract}
We present surveys of derbid planthoppers associated with coconut (Cocos nucifera L.) and oil palm (Elaeis guineensis Jacq.) collected in Northeastern (Sergipe) and North (Pará and Roraima) Brazil. The surveys were intended to contribute to our knowledge of possible vectors of phytoplasmas or other phloem-restricted plant pathogens. Eight derbid taxa were found, two in the subfamily Cedusinae, tribe Cedusini (Cedusa yipara Kramer and C. yowza Kramer) and six in the subfamily Derbinae, tribe Cenchreini: Herpis sp., Persis pugnax Stål, Omolicna anastomosa (Caldwell), O. nigripennis (Caldwell), and two new species in the genus Agoo Bahder \& Bartlett are described here. Genus-level features between Omolicna and Agoo are discussed and a key to the species of Agoo is provided.
\end{abstract}

\section{Introduction}

Coconut tree (Cocos nucifera L.) is the fourth most important perennial fruit tree in Brazil, with approximately 158,477 ha of cultivated area (IBGE 2018). Eighty-five percent of the plantations cover less than 10 ha and are in the hands of small farmers, the rest concerns big private agro-industrial companies (Fontes \& Wanderley 2006, Martins \& Jesus Júnior 2014). Over the last 20 years, coconut water has become one of the most important high value-added products of the agroindustry of Brazil (Fontes \& Wanderley 2006) and the country is the world's fourth largest producer of coconuts (FAO 2020).

Given the importance of coconut in Brazil, the arrival of a serious disease such as lethal yellowing (LY) would be catastrophic (Dollet \& Talamni 2018). In Jamaica, LY has caused the death of millions of coconuts and it has destroyed $90 \%$ of the coconuts of the Atlantic coast of Honduras in less than 10 years (McGrath 2002, Rocca 2013). LY was reported in more than 30 species of palms in Florida (Dollet \& Talamani 2018, Sullivan \& Harrison 2013), suggesting that the disease may be a broad threat to indigenous palms in Amazonian region. Valuable palms that might be threatened include the açai palm (Euterpe oleracea Mart. and E. precatoria Mart.), the buriti palm (Mauritia flexuosa L. f.), babaçu (Attalea speciosa Burret), pupunha (Bactris gasipaes Kunth), and others that are important sources of food and other products (Balick 1979, Kahn 1991, Mtiiz-Miret et al 1996, Brondizio 2011, Tunçer \& Schroeder 2017). 
LY is caused by phytoplasmas that are phloem-limited pathogens transmitted by insects that feed exclusively on phloem tissue (McCoy et al 1983, Eden Green 1997, Dollet et al 2009). Known vectors of phytoplasmas are in the order Hemiptera, suborder Auchenorrhyncha, mostly families Cixiidae and Cicadellidae (subfamily Deltocephalinae). Derbidae and Flatidae also have been suggested as possible vectors (Mpunami et al 2000, Clair et al 2001, Wilson 2005, Weintraub \& Beanland 2006, Philippe et al 2007, Philippe et al 2009, Lee \& Wilson 2010, Rodrigues et al 2010, Rajan 2013, Halbert et al 2014).

For this reason, surveys for early detection of LY and potential vectors are being made in Brazil. Here, we report Derbidae found during surveys of coconut and oil palm (Elaeis guineensis Jacq.) in Northeastern (Sergipe) and North (Pará and Roraima) Brazil. Two of the species found are described as new species and a key to the species of Agoo Bahder \& Bartlett is provided.

\section{Material and Methods}

\section{Study areas and survey methods}

Surveys were undertaken in Roraima state, North of Brazil, from July to August 2016 in the following municipalities: Boa Vista, Bonfim, Mucajaí, and Rorainópolis, and in October 2017 in Boa Vista, Cantá, Mucajaí, São João da Baliza, and São Luis (Fig 1). Coconut plantations (Cocos nucifera L., Arecaceae) were visited in those municipalities in order to identify plants with LYTS and the presence of potential insect vectors, leafhoppers, and planthoppers. Oil palm plantations (Elaeis guineensis Jacq., Arecaceae) were also visited in the south of the State for searching vectors. All plants were observed for symptoms similar to LYTS in leaves of the basal third or at least 20 plants of each plantation. Planthoppers were collected with a mouth-aspirator or caught with a tube and preserved in $70 \%$ alcohol.

Derbidae were also collected on the lower leaves of coconuts in the Coconut International Bank for Latin America and the Caribbean (ICG-LAC) located in Itaporanga D'Ajuda, Sergipe State, in Northeastern Brazil. Other derbids were collected using sweeping net and mouth aspirator in a plantation (Brazilian Green Dwarf Jiqui) of Northern Pará state in Santa Izabel do Pará. Insects were collected on the lower leaves of the palms. Information about sampled plantations and geographic coordinates are provided in Table 1 and Fig 1. Derbids were sorted to morphospecies with representative specimens donated to the Museu Paraense Emílio Goeldi, São Bráz, Belém, Pará, Brazil (MPEG), and subsequently loaned to CRB for identification, with representative (nontype) specimens retained at the University of Delaware Reference Collection, Newark, DE (UDCC), by permission of
MPEG. Additional study specimens are deposited in Embrapa (Empresa Brasileira de Pesquisa Agropecuária) in Aracaju and Roraima, Brazil.

\section{Morphological terminology and specimen techniques}

Abdomens were cleared by soaking in $10 \% \mathrm{KOH}$ solution overnight (or $20 \%$ hot $\mathrm{KOH}$ for $\sim 15 \mathrm{~min}$ ) for examination. Morphological terminology generally follows that of Bartlett et al (2014), except forewing venation following Bourgoin et al (2015) and with male terminalia nomenclature modified after Bourgoin (1988) and Bourgoin \& Huang (1990). Authorship of the two new species should be attributed to Bahder and Bartlett.

Photographs and measurements were taken using a digital imagery system. Line art was digitally traced from photographs. All measurements are in millimeters $(\mathrm{mm})$. Specimen measurements were taken for descriptive (not statistical) purposes and are from type material.

Label information of holotypes types is quoted, with ' $/$ indicating new line and '//' indicating next label and with supplemental information given in brackets. For other material examined, label data were rewritten to maintain consistency in pattern, beginning with the country, state or province, and more specific locality, followed by the collection date, collector, and lastly, the number, sex of specimens, and specimen depository given in parentheses. Type material and other specimens examined at UDCC were provided with 2D barcode labels and data captured using "Arthropod Easy Data Capture" (Schuh et al 2010, Schuh 2012, Arthropod Easy Capture 2013) in the NSF sponsored "Tri-Trophic Thematic Collection Network" (Tri-Trophic TCN, http://tcn.amnh.org/). These data are available via the iDigBio (www.idigbio.org) specimen portal.

\section{Identification and classification}

Derbid specimens were identified to higher taxon following Metcalf (1938) and Fennah (1952) as updated by O'Brien (1982) and Emeljanov (1992, 1996). Species level identifications used available keys and illustrations, and in some cases by comparison with photos of primary type material. The genus Cedusa Fowler was identified using Flynn \& Kramer (1983) and Kramer (1986); Omolicna Fennah by Caldwell (1944), Fennah (1945), Halbert et al (2014), and Bahder et al (2019); Herpis Stål using Metcalf $(1938,1945)$ and O'Brien (1982, 1987); Persis Stål using Metcalf (1938) and Fennah (1945, 1952). The status of Agoo Bahder \& Bartlett was recently revised by Bahder et al (2020a) from a subgenus of Omolicna to full genus status. Photos of type material of Persis pugnax Stål, Herpis fuscovittata Stål, Phaciocephalus fimbriolata (Stål), P. orba (Stål), and P. pallidovenosa (Stål) 


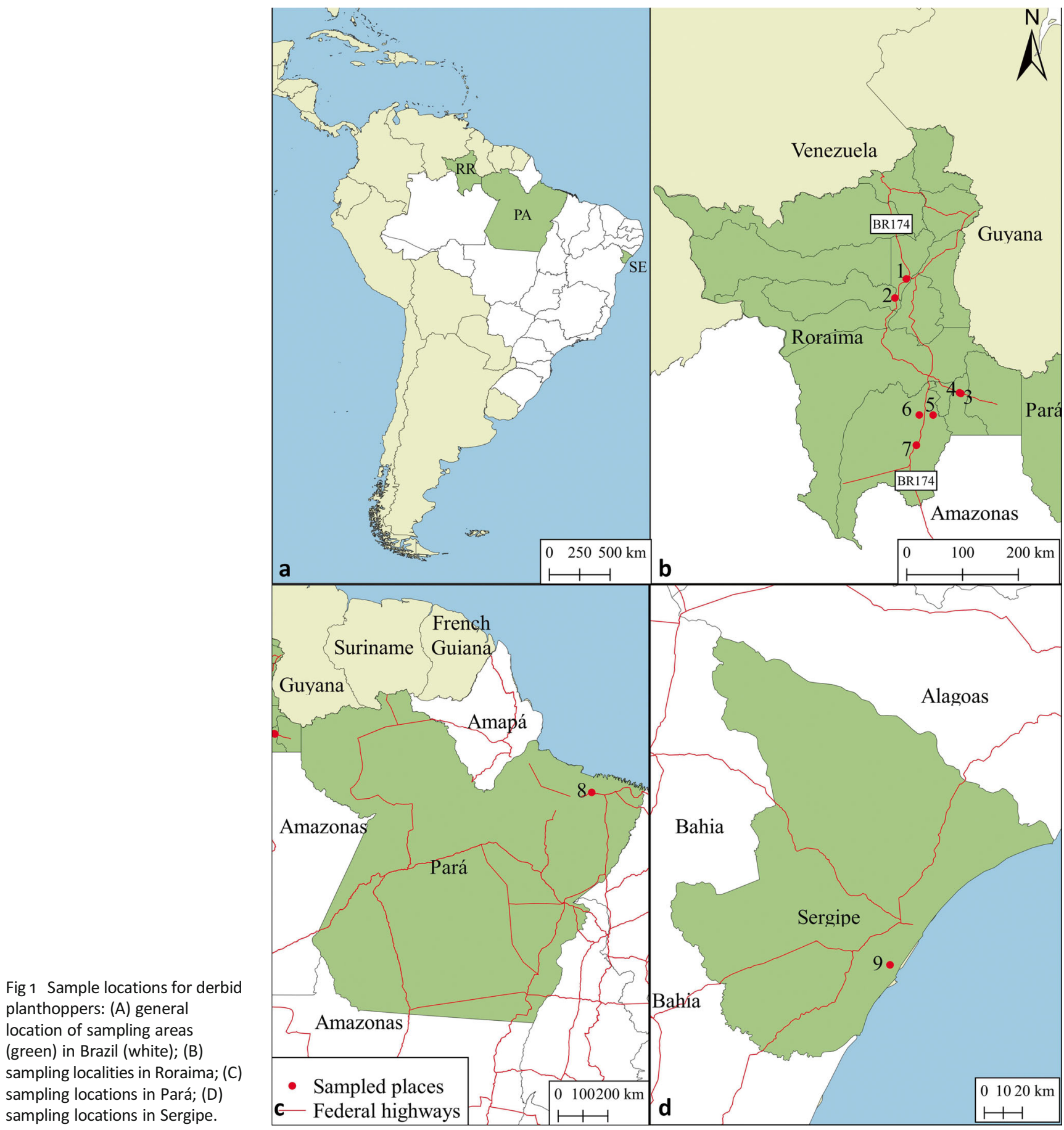

were obtained from the Swedish Museum of Natural History in Stockholm for comparison with field collected specimens.

\section{Results}

Eight taxa from the family Derbidae were found associated with palms in these surveys (Table 1). Of these, two were in the genus Cedusa Fowler (Cedusinae: Cedusini). This genus comprises 148 species in the New World and 32 in Africa, although the latter taxa are probably better placed in Malenia Haupt (Fennah 1961, Szwedo 2006). Species of Cedusa are often externally very similar and recognition relies almost entirely on features of male terminalia (Flynn \& Kramer 1983, Kramer 1986). Cedusa has previously been suggested as a possible vector of lethal yellowing phytoplasmas in Jamaica (Brown et al 2006). However, no experimental transmission of LY was obtained in Jamaica. 
Table 1 Derbidae species associated with coconut and oil palm in Brazil.

\begin{tabular}{|c|c|c|c|c|}
\hline \multirow[t]{2}{*}{ Species } & \multirow[t]{2}{*}{ Host } & \multicolumn{3}{|l|}{ Sampled place } \\
\hline & & State/municipality/locality & Geographical coordinates & Number on map (Fig 1) \\
\hline \multirow[t]{3}{*}{ Cedusa yipara Kramer } & Oil palm & Roraima, São João da Baliza & $0^{\circ} 56^{\prime} 02,3^{\prime \prime} \mathrm{N}, 59^{\circ} 52^{\prime} 39,6^{\prime \prime} \mathrm{W}$ & 3 \\
\hline & Coconut & Roraima, Rorainopolis, Vila Nova Colina & $0^{\circ} 35^{\prime} 17,7^{\prime \prime} \mathrm{N}, 60^{\circ} 19^{\prime} 15,8^{\prime \prime} \mathrm{W}$ & 5 \\
\hline & Coconut & Pará, Santa Isabel do Pará, Sococo & $01^{\circ} 14.744^{\prime S}, 048^{\circ} 03^{\prime} 53,3^{\prime \prime W}$ & 8 \\
\hline Cedusa yowza Kramer & Oil palm & Roraima, Rorainopolis, Vila Equador & $00^{\circ} 06^{\prime} 12,5^{\prime \prime} \mathrm{N}, 60^{\circ} 35^{\prime} 26,6^{\prime \prime} \mathrm{W}$ & 7 \\
\hline Herpis sp. & Coconut & Roraima, São João da Baliza & $0^{\circ} 56^{\prime} 07,9^{\prime \prime} \mathrm{N}, 59^{\circ} 52^{\prime} 40,4^{\prime \prime} \mathrm{W}$ & 4 \\
\hline \multirow[t]{2}{*}{ Persis (Persis) pugnax Stål } & Coconut & Roraima, Boa Vista & $\mathrm{O} 2^{\circ} 47^{\prime} \mathrm{O} 2,6^{\prime \prime} \mathrm{N}, 60^{\circ} 45^{\prime} 12,5^{\prime \prime} \mathrm{W}$ & 1 \\
\hline & Coconut & Roraima, Mucajaí & $02^{\circ} 28^{\prime} 34,9^{\prime \prime} \mathrm{N}, 60^{\circ} 56^{\prime} 11,9^{\prime \prime} \mathrm{W}$ & 2 \\
\hline Omolicna anastomosa (Caldwell) & Coconut & Sergipe, Itaporanga D’Ajuda & $11^{\circ} \mathrm{O} 6^{\prime} 14,5^{\prime \prime} \mathrm{S}, 37^{\circ} 11^{\prime} \mathrm{O} 3,8^{\prime \prime} \mathrm{W}$ & 9 \\
\hline \multirow[t]{3}{*}{ Omolicna nigripennis (Caldwell) } & Coconut & Roraima, Rorainopolis, Vila Nova Colina & $0^{\circ} 35^{\prime} 23,2^{\prime \prime} \mathrm{N}, 60^{\circ} 32^{\prime} 38,6^{\prime \prime} \mathrm{W}$ & 6 \\
\hline & Oil palm & Roraima, Rorainopolis, Vila Equador & $00^{\circ} 06^{\prime} 12,5^{\prime \prime} \mathrm{N}, 60^{\circ} 35^{\prime} 26,6^{\prime \prime} \mathrm{W}$ & 7 \\
\hline & Coconut & Sergipe, Itaporanga D’Ajuda & $11^{\circ} 06^{\prime} 14,5^{\prime \prime S}, 37^{\circ} 11^{\prime} 03,8^{\prime \prime} \mathrm{W}$ & 9 \\
\hline \multirow[t]{3}{*}{ Agoo argutiola sp. $\mathrm{n}$. } & Oil palm & Roraima, Rorainopolis, Nova Colina & $00^{\circ} 36^{\prime} 47,85^{\prime \prime N}, 60^{\circ} 17^{\prime} 40,57^{\prime \prime} \mathrm{W}$ & 3 \\
\hline & Coconut & Roraima, Boa Vista & $\mathrm{O} 2^{\circ} 47^{\prime} \mathrm{O} 2,6^{\prime \prime} \mathrm{N}, 60^{\circ} 45^{\prime} 12,5^{\prime \prime} \mathrm{W}$ & 1 \\
\hline & Coconut & Roraima, São João da Baliza & $0^{\circ} 56^{\prime} 54,8^{\prime \prime} \mathrm{N}, 59^{\circ} 53^{\prime} 41,2^{\prime \prime} \mathrm{W}$ & 4 \\
\hline Agoo spina sp. $\mathrm{n}$. & Coconut & Sergipe, Itaporanga D’Ajuda & $11^{\circ} \mathrm{O} 6^{\prime} 14,5^{\prime \prime} \mathrm{S}, 37^{\circ} 11^{\prime} \mathrm{O}, 8^{\prime \prime} \mathrm{W}$ & 9 \\
\hline
\end{tabular}

The remaining derbid species were all in the Derbinae, tribe Cenchreini. The extant Cenchreini consists of 22 genera and 186 species, of which 10 genera and 59 species occur in the New World (two genera, as currently defined, occur in both hemispheres) (Bourgoin 2020). These taxa consisted of Persis punax Stål, Herpis sp. and five species in or near the genus Omolicna Fennah.

\section{Taxa found associated with coconut and oil palm in Brazil}

1. Cedusa yipara Kramer, 1986. One specimen (sample SJ1C) (Fig 2A); 20-II-2017; Roraima State, São João da Baliza, $0^{\circ} 56^{\prime} 02.3^{\prime \prime} \mathrm{N}, 59^{\circ} 52^{\prime} 39.6^{\prime \prime} \mathrm{W}$, oil palm, Michel Dollet \& Elisangela Fidelis leg. One specimen (sample 22936) Rorainopolis, Vila Nova Colina, 01¹4.744'S, 04803.533'W, 3-VIII-2016, coconut, Michel Dollet \& Elisangela Fidelis leg.; one specimen Pará, Sococo, Santa Isabel do Pará, $01^{\circ} 14.71030^{\prime} S$, $048^{\circ} 03.533^{\prime} \mathrm{W}$, 18-V-2016, coconut, Eliana Passos \& Flaviana Silva leg. In addition, there were three females tentatively referred to this species (Sergipe, Itaporanga D'Ajuda, $11^{\circ} 06^{\prime} 14.5^{\prime \prime S}, 37^{\circ} 11^{\prime} 03.8^{\prime \prime} \mathrm{W}, 22-\mathrm{VII}-2015$, coconut, Eliana Passos \& Flaviana Silva). Cedusa Fowler is a difficult genus, and if defined as entirely New World (e.g., by Szwedo 2006, as opposed to the doubtfully distinct Malenia Haupt), consists of 148 extant species, most of which are Neotropical. Cedusa has been revised by Flynn \& Kramer (1983) and Kramer (1986), which collectively treated 147 species in the genus, plus $C$. quixoa Kramer, subsequently moved to Cedochrusa Emeljanov (Emeljanov 2008), separated principally by features of the male genitalia. Cedusa yowza Kramer (reported below), previously reported from Panama, is (as noted by Kramer 1986) very similar to Cedusa yipara, separated from this species by the aedeagal flagellum (endosoma) terminating with semicircular process bearing a subapical fin and apical microteeth (in C. yowza, see Kramer 1986, Fig 80), versus flagellum terminating truncately (Kramer 1986, Fig 83). The C. yipara specimen from Vila Nova Colina differs in having the apical process on the left side of the aedeagus not distinctly forked and the right paramere not as narrowed. Further investigation is needed to determine the variation found in $C$. yipara and whether there are undescribed species of Cedusa on palms in Brazil.

2. Cedusa yowza Kramer. One male, Roraima, Rorainopolis, Vila Equador, $00^{\circ} 06^{\prime} 12.5^{\prime \prime} \mathrm{N}, 60^{\circ} 35^{\prime} 26.6^{\prime \prime}$ W, 2-VIII-2016, Elaeis guineensis Jacq., Michel Dollet \& Elisangela Fidelis leg.

3. Herpis sp. One male (sample SJ4C) (Fig 3), Roraima State in Brazil, São João da Baliza, $0^{\circ} 56^{\prime} 53.3^{\prime \prime} \mathrm{N}, 59^{\circ} 53^{\prime}$ 42.0"W, coconut, 21-II-2017, Michel Dollet \& Elisangela Fidelis leg. The genus Herpis Stål consists of the 12 species, three are reported from South America, four are Indomalayan and probably misplaced at the genus level; the balance of species are Mesoamerican. We have not been able to match the single obtained specimens with any of the described species, including any of the three species known from South America. This genus is poorly known from Brazil, with Herpis fuscovittata Stål, the only species previously reported 
Fig 2 Lateral habitus of derbid planthopper species: (A) Cedusa yipara; (B) Omolicna nigripennis; (C) Persis pugnax.
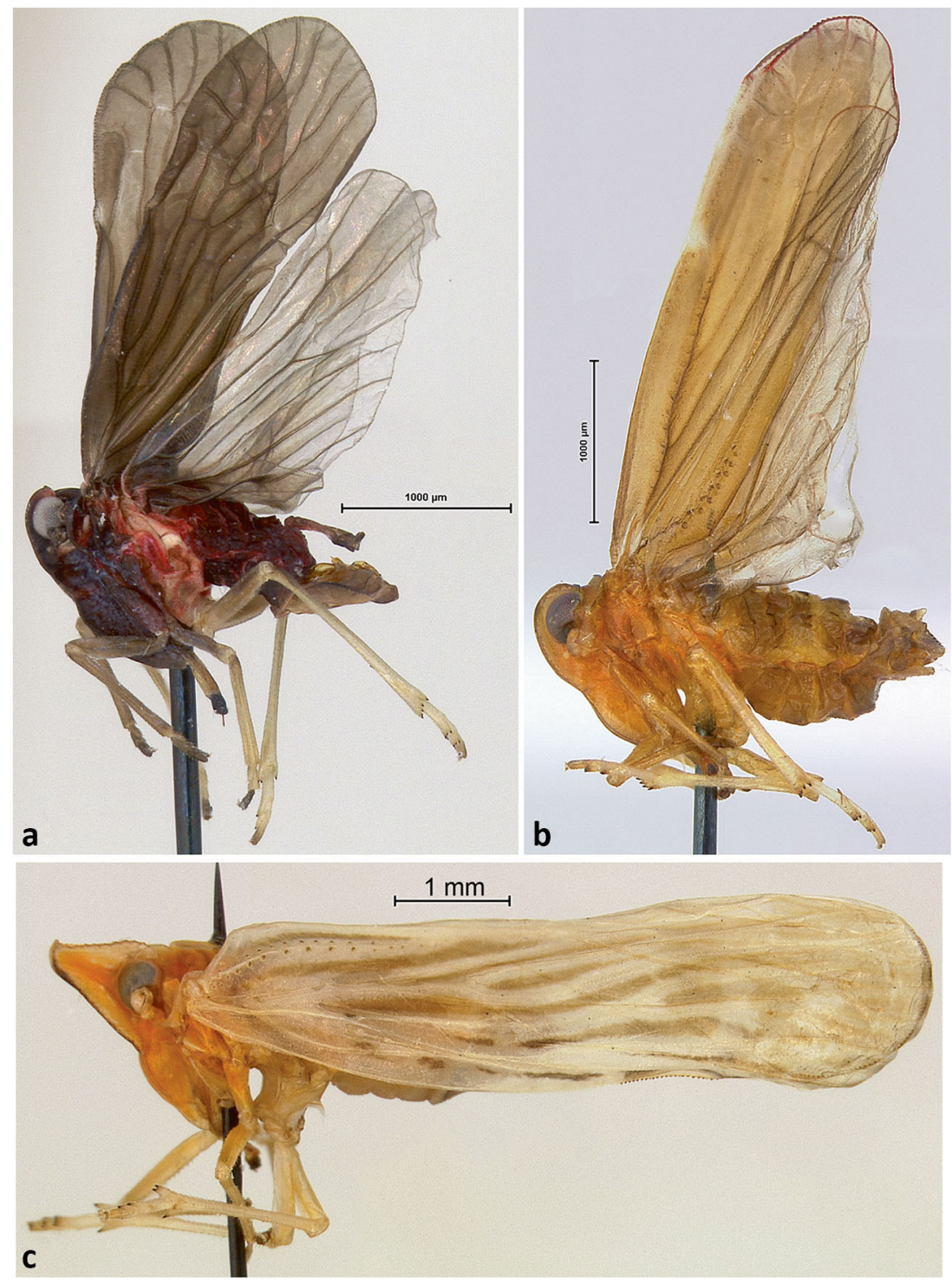

from Brazil, and the type species of the genus. We obtained photographs of the type specimen of Herpis fuscovittata from the Swedish Museum of Natural History, Stockholm (NHRS-GULlo00058748), which showed $H$. fuscovittata to be a much paler species. This specimen does not appear to match the descriptions of either of the other two species reported from South America (viz., H. chiriquensis (Fowler), reported from Guyana and Panama, and H. metcalfi O'Brien from Guyana (as British Guiana; Muir 1918, Metcalf 1945, O'Brien 1987). The specimen probably represents an undescribed species, but we have not definitively been able to exclude the described Mesoamerican species because of incomplete original descriptions and limited accessibility to type material.

4. Persis (Persis) pugnax Stål. One male (sample 22937) (Fig $2 \mathrm{C}$ ) from Roraima, Roraima, Boa Vista, $2^{\circ} 47^{\prime} 02.6^{\prime \prime}$ $\mathrm{N}, 60^{\circ} 45^{\prime} 12.5^{\prime \prime} \mathrm{W}$, coconut, 26-VII-2016, Michel Dollet
\& Elisangela Fidelis leg; 2 specimens (1 male, 1 female, 22,940), Mucajaí, Roraima, $2^{\circ} 28^{\prime} 34.9^{\prime \prime} \mathrm{N}, 60^{\circ} 56^{\prime} 11.9^{\prime \prime} \mathrm{W}$, coconut, 28-VII-2016, Michel Dollet \& Elisangela Fidelis leg. Species identification confirmed by comparison with photographs of two syntype specimens from the Swedish Museum of Natural History, Stockholm (\#NHRS-GULIO00040282, NHRS-GULI000040281).

5. Omolicna anastomosa (Caldwell). One male, Sergipe, Itaporanga D'Ajuda, $11^{\circ} 06^{\prime} 14.5^{\prime \prime} \mathrm{S}, 37^{\circ} 11^{\prime} 03.8^{\prime \prime} \mathrm{W}$, coconut, 19-V-2016, Eliana Passos \& Flaviana Silva, aspirator.

6. Omolicna nigripennis (Caldwell). One male (sample 22935) (Fig 2B), Roraima, Rorainopolis, Vila Nova Colina, $0^{\circ} 35^{\prime} 23.2^{\prime \prime} \mathrm{N}, 60^{\circ} 32^{\prime} 38.6^{\prime \prime} \mathrm{W}$, coconut, 2-VIII2016, Michel Dollet \& Elisangela Fidelis leg; one male (sample 22932), Roraima, Rorainopolis, Vila Ecuador, $00^{\circ} 06^{\prime} 12.5^{\prime \prime} \mathrm{N}, 60^{\circ} 35^{\prime} 26.6^{\prime \prime} \mathrm{W}$. Oil palm, Michel Dollet \& Elisangela Fidelis leg; Sergipe, Itaporanga D’Ajuda, 
Fig 3 Herpis sp.: (A) dorsal habitus; (B) lateral habitus.
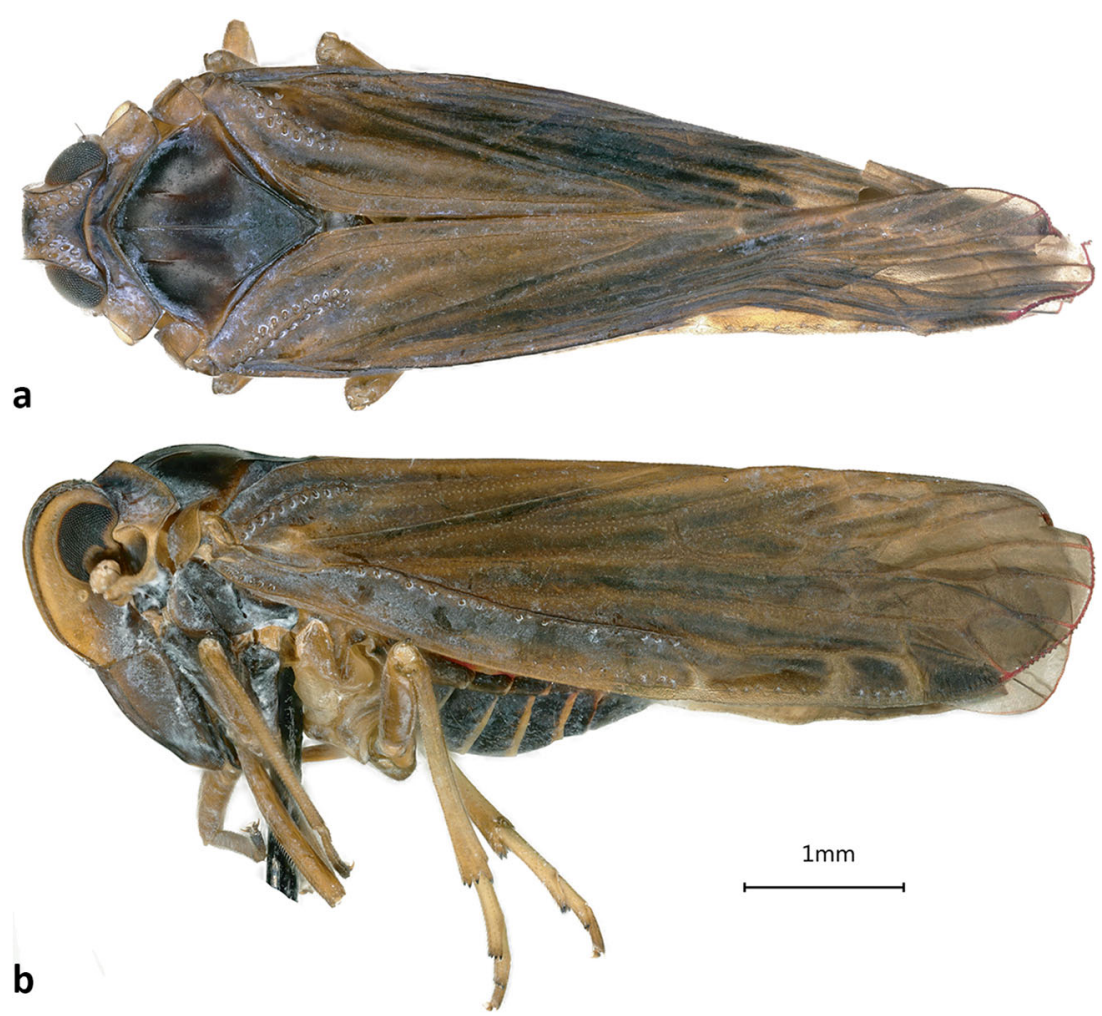

$11^{\circ} 06^{\prime} 14.5^{\prime \prime S}, 37^{\circ} 11^{\prime} 03.8^{\prime \prime} \mathrm{W}$, coconut, 31-VII-2015, Eliana Passos \& Flaviana Silva, sweep net. Omolicna specimens identified with Caldwell (1944) using features of male terminalia.

7. Agoo argutiola sp. n. Four males (Fig 4), Roraima, Rorainopolis, Nova Colina, $00^{\circ} 36^{\prime} 48.7^{\prime \prime} \mathrm{N}, 60^{\circ} 17^{\prime} 39.7^{\prime \prime}$ W, oil palm, 3-VIII-2016, Michel Dollet \& Elisangela
Fidelis leg; one male from Roraima, Boa Vista, $2^{\circ} 47^{\prime}$ $02.6^{\prime \prime} \mathrm{N}, 60^{\circ} 45^{\prime} 12.5^{\prime \prime} \mathrm{W}$, coconut, 27-VII-2016, Michel Dollet \& Elisangela Fidelis leg; one male (sample SJ4b), Roraima, São João da Baliza, $0^{\circ} 56^{\prime} 07.9 " \mathrm{~N}$, $59^{\circ} 52^{\prime} 40.4^{\prime \prime} \mathrm{W}$, coconut, 21-III-2017, Michel Dollet \& Elisangela Fidelis leg; two females and one male (SJ4d) Roraima, São João da Baliza, $0^{\circ} 56^{\prime} 07.9^{\prime \prime} \mathrm{N}$,
Fig 4 Agoo argutiola sp. $\mathrm{n}$. (paratype): (A) lateral view, habitus; (B) terminalia, left lateral view; (C) apex of hind leg, ventral view.
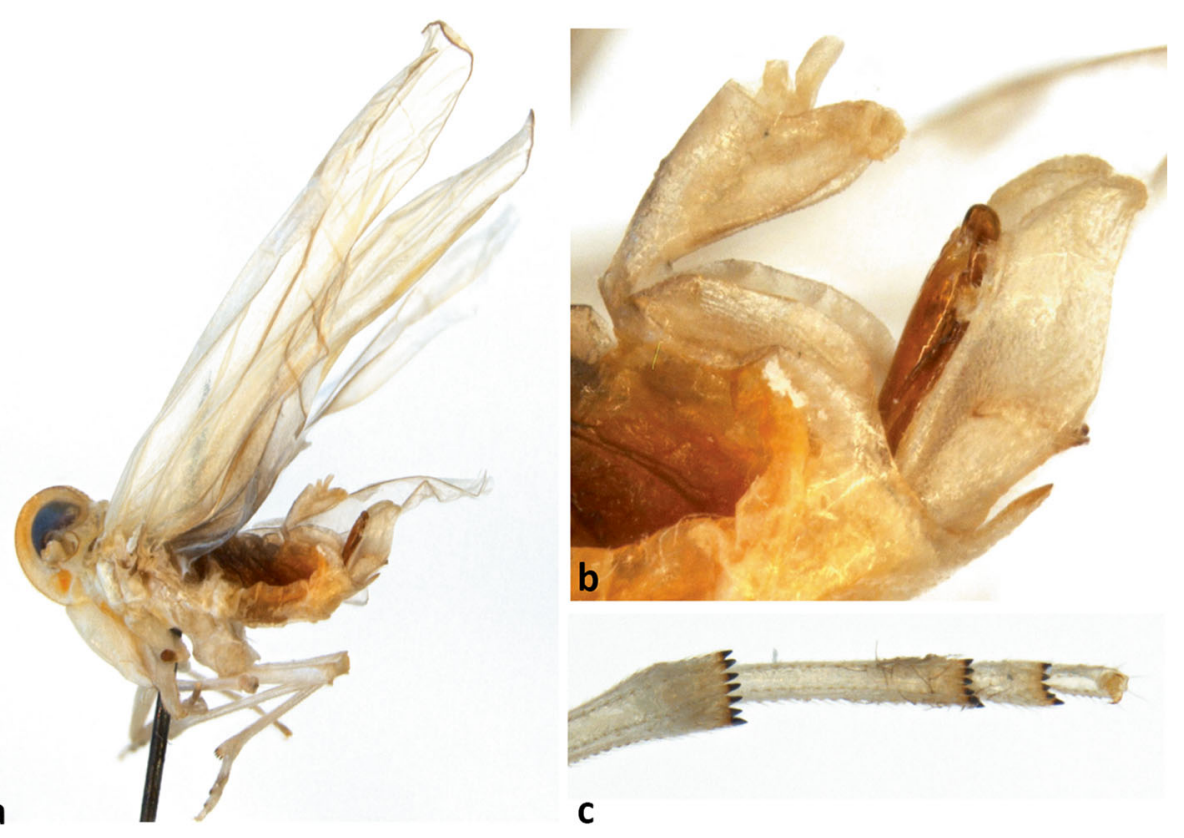
$59^{\circ} 52^{\prime} 40.4^{\prime \prime} \mathrm{W}$, coconut, (20-21)-III-2017 (an additional specimen from this locality appears slightly different and is excluded from the paratype series). This species falls into Agoo Bahder \& Bartlett (in Bahder et al 2019) and is described below. Agoo recently changed status from subgenus of Omolicna to full genus by Bahder et al (2020a).

8. Agoo spina sp. n. One specimen (Fig 8) from Sergipe, Itaporanga D'Ajuda, $11^{\circ} 06^{\prime} 14.5^{\prime \prime} \mathrm{S}, 37^{\circ} 11^{\prime} 03.8^{\prime \prime} \mathrm{W}$, coconut, 22-VII-2015, Eliana Passos \& Flaviana Silva, sweep net; two specimens same except 19-V-2016, aspirated from coconut. This species similar to Agoo argutiola sp. n. but differs in details of color and in male terminalia.

\section{Systematics}

Family Derbidae Spinola, 1839

Subfamily Derbinae Spinola, 1839

Tribe Cenchreini Muir, 1913

\section{Genus Agoo Bahder \& Bartlett, 2019}

Type species: Agoo xavieri Bahder \& Bartlett, 2019

Amended diagnosis. The members of Agoo are pale forms, with the head in lateral view appearing smoothly rounded from posterior margin of vertex to the frontoclypeal suture. The lateral carinae of the vertex and frons are foliate such that the vertex and frons are concave. The median carina of the vertex and frons appears absent and there is no transverse carina at the fastigium. The frons narrower and paranota more strongly foliate than Omolicna. The terminalia are nearly bilaterally symmetrical; the aedeagus is stout with a strongly retrorse flagellum bearing differing, symmetrical arrangements of processes. The ventral lobe of pygofer (ventral view) broad, distally attenuating to rounded apex. Anal tube is stout, elongate, and ventrally sinuate.

Remarks. The genus Agoo (originally a subgenus of Omolicna) is most readily separated from Omolicna by the foliate carinae of the head, the profile of the head being strongly rounded, and the more strongly foliate antennal fossae compared with Omolicna. The terminalia of Agoo are nearly bilaterally symmetrical (more so than Omolicna), and the midventral lobe of the opening of the pygofer is elongately rounded, and the anal tube is ventrally sinuate (lacking convexity found in most Omolicna). Bahder et al (2019) showed a high pairwise distance between Agoo xavieri Bahder \& Bartlett and five species of Omolicna, with a percent nucleotide difference range from 24.4 to $31.1 \%$ for $\mathrm{CO} 1$ and $\sim 10.6 \%$ for a 1493 bp region of $18 \mathrm{~S}$.

At present, all members of the genus Agoo are associated with palms (Arecaceae).

In the key to genera of Cenchreini presented by O'Brien (1982, modified from Fennah 1952), species of Agoo key with difficulty because of several ambiguous features (carinae of vertex pustulate; frons narrow, compressed; subantennal fovea present, subcostal cell long, Sc+R fork about level with Cu1 fork and union of claval veins, claval apex in basal half of wing). Depending on interpretation of features, Agoo might key to Cenanges Fennah, Neocenchrea Metcalf, or Phaciocephalus Stål. Cenanges and Neocenchrea can be excluded based on an examination of specific features, especially male genitalia (photos of the type specimen of Cenanges spectralis Fennah from The Natural History Museum, London were examined). Phaciocephalus appears to be paraphyletic, with 28 species, principally from the Indomalayan region and Oceania except for 3 species (doubtfully included) from Brazil. Photographs of the type specimens of the Brazilian Phaciocephalus were obtained from the Swedish Museum of Natural History, Stockholm, to compare with the new species of Agoo.

Preliminary key to separate Omolicna and Agoo and species of Agoo

1. Frons and vertex relatively broad (e.g., Caldwell 1944, plate I, Fig 4), lateral margins keeled but not foliate, disk of depressed, posterior margin of vertex varies, but usually not quadrately concave; head profile in lateral view somewhat flattened on frons; phallotheca bilaterally asymmetrical, ventral lobe of pygofer opening (ventral view) varied, but often with lateroapical teeth (e.g., Caldwell 1944, Figs 5B); ventral margin of anal tube from lateral view with subapical concavity (e.g., Caldwell 1944, Fig 1C) genus Omolicna

- Frons and vertex narrow (Fig 5A, B), lateral margins foliate, disk deeply concave, posterior margin of vertex quadrantally concave; head in lateral view smoothly rounded from posterior margin of vertex to frontoclypeal suture (Fig $5 \mathrm{C}$ ); phallotheca nearly bilaterally symmetrical, ventral lobe of pygofer opening (ventral view, Fig $7 A$ ) with elongately rounded lobe (subtriangular); ventral margin of anal tube sinuate, without subapical concavity (Figs 7C)............................................................ genus Agoo ...2

2. Wings lacking distinct markings; Trinidad, Brazil .......... 3

- Wings with spots or longitudinal bands (or both); Costa Rica ..................................................................... 5

3. Aedeagal shaft with pair of slender spines on dorsolateral margin about 2/3 from base (Fennah 1945, Fig 164); apical margin of forewing bordered with pink; Trinidad ...................................... Agoo rubrimarginata

- Aedeagal shaft without lateral spines except at apex; apical margin of forewing not pink; Brazil .................... 4

4. Lateral margin of pygofer opening with acuminate medially directed lobe (Fig 10G); gonostyli in ventral view with medially directed lobe irregularly lobed on trailing margin (Figs $10 \mathrm{H}$ and 11B); phallothecal flagellum with a pair of dorsal elongate retrorse processes (Fig 10D, E) .................................................... Agoo spina sp. n. 
- Lateral margin of pygofer opening lacking acuminate medially directed lobe (Fig $7 \mathrm{C}$ ); gonostyli in ventral view with medially directed lobe bearing 2 short sclerotized spines on inner margin (Fig 7B); phallothecal flagellum without dorsal retrorse processes (Figs 6D, E) Agoo argutiola sp. $\mathrm{n}$.

5. Wings with black spots, without distinct stripe (Bahder et al 2020a, Fig 7); dorsal surface of gonostyli bearing large lobe with a median invagination resulting in two processes (Bahder et al 2020a, Fig 10A), pair of processes on aedeagus situated posterior ................... Agoo dahliana

- Wings with distinct longitudinal stripe; processes lacking on dorsal surface of gonostyli ... 6

6. Stripe on forewing terminating in red with distal black spot (Bahder et al 2020b, Fig 5); gonostyli with sclerotized ridge on outer lateral margin near midlength bearing sharp projection (Bahder et al 2020b, Fig 6A) Agoo luzdenia

- Stripe on forewing fuscous (Bahder et al 2019, Fig 2), gonostyli lacking lateral ridge (Bahder et al 2019, Fig 4A) Agoo xavieri

\section{Agoo argutiola Bahder \& Bartlett sp. n.}

(Figs 4, 5, 6, 7, 12A, and 13A)

Type locality. Roraima, Rorainopolis, Nova Colina.

Diagnosis. Male pygofer with median ventral process broad near base, attenuating distally to broadly rounded apex (lateral teeth lacking); lateral margins of pygofer opening lacking transversely projecting processes. Gonostyli in ventral view with medially directed lobe bearing two sclerotized spines on inner margin. Flagellum of aedeagus lacking dorsal processes arising near junction of aedeagal shaft.

Description. Color. General body color pale, stramineous; face orange on dorsal portion of frons and genae; however, some individuals are a uniform pale yellow (Fig $5 \mathrm{~A}$ ); lateral carinae of front and vertex darker. Wings transparent (Fig 12A), almost white basally, diffusely infuscated distally.

Structure. Body length (without wings) males: 2.99$3.45 \mathrm{~mm}(n=2)$, females: $2.94-3.52 \mathrm{~mm}(n=2)$; body length (with wings): not available (specimens with wings splayed). Head. Anterior margin of head, in lateral view, rounded (Fig 5C) from posterior margin of vertex to frontoclypeal suture. Vertex deeply depressed (Fig 5B), median carinae absent, quadrantally concave posteriorly, notched distally, broadest near base, tapering anteriorly; lateral carinae foliately keeled, bearing row of (sensory?) pits. Transverse apical carina at fastigium absent. Vertex length males: $0.39-0.45 \mathrm{~mm}$; females: $0.41-0.43 \mathrm{~mm}$. Vertex width at hind margin males: $0.33-0.41 \mathrm{~mm}$; females: $0.37-0.38 \mathrm{~mm}$. Vertex width at distal margin males: 0.11-0.13 mm; females: 0.12-0.14 mm. Frons with lateral carinae strongly keeled, narrowest between compound eyes, diverging slightly ventral to become parallel between ocelli and frontoclypeal suture (Fig 5A); pits on foliate carinae for entire length, median carinae absent. Lateral ocelli faintly indicated. Antennal scape very short ( $0.09 \mathrm{~mm}$ ), pedicel larger ( $0.21 \mathrm{~mm}$ ), bulbous, with irregularly arranged sensillae, flagellum short $(\sim 0.20 \mathrm{~mm})$. Frons length males: $0.84-0.86 \mathrm{~mm}$; females: $0.84-1.01 \mathrm{~mm}$. Frons dorsal width males: $0.10-0.11 \mathrm{~mm}$; females: $0.12-0.13 \mathrm{~mm}$. Frons frontoclypeal margin width, males: $0.22 \mathrm{~mm}$; females: $0.22-0.26 \mathrm{~mm}$. Clypeus elongate, broadest near frontoclypeal margin, tapering distally to labrum; median carina present, lateral carinae weakly keeled, pits absent. Clypeus length males: $0.62-0.68 \mathrm{~mm}$; females: $0.62-$ $0.71 \mathrm{~mm}$.

Thorax. Pronotum short (length at midline males: $0.23-$ $0.27 \mathrm{~mm}$; females: $0.24-0.25 \mathrm{~mm}$ ), anterior margin following contours of head (Fig 5B; medially convex and truncate behind vertex, narrowed behind eyes). Median carina of pronotum obsolete, lateral carinae distinct, reaching caudal margin; anterior keel following anterior margin of pronotum behind eye to antennal fossa in paradiscal field (Fig 5 C); in lateral view, posterior margin of pronotum inflected upward; paradiscal field with deep fossae with foliately keeled margins (forming "cup" posterior to antennae, partially surrounding antennae both dorsad and ventrad. Mesonotum appearing slightly elevated in lateral view (Fig $5 \mathrm{C}$ ), in dorsal view with 3 subparallel longitudinal carinae, indistinctly reaching scutellum; scutellum distinctly indicated by transverse groove, posteriorly inflected upward, dorsolateral angles of scutellum bearing projections (may be hidden by forewings in repose). Mesonotum length at midline (including scutellum) males: $0.68-0.75 \mathrm{~mm}$; females: $0.50-0.65 \mathrm{~mm}$. Mesonotum width males: $0.93-1.05 \mathrm{~mm}$; females: $0.91-$ $0.95 \mathrm{~mm}$.

Forewing (Figs. 12A and 13A) with a row of pits along basal $1 / 2$ of ScP+R and basal half of postcubitus. Cluster of pits between RA and ScP and two rows of four sensory pit basad of ScP. Forks of $R$ and CuA veins at approximately the same level, both well proximad of claval apex, but near level of Pcu+1A fusion. Claval apex just near midpoint of wing, fork of $M$ near claval apex. Branching pattern: Sc and RA unbranched, RP 2-branched, MP 4-branched and CuA 2branched plus short branch at claval apex. Fusion of Pcu+A1 in proximal third (A1 closely approximate to trailing margin of wing). Forewing length males: $5.4-5.8 \mathrm{~mm}$; females: $5.5^{-}$ $5.9 \mathrm{~mm}$.

Terminalia. Pygofer, in lateral view, widest at base, abruptly narrowed to irregularly sinuate margins, anterior concave, caudal convex (Fig $7 \mathrm{C}$ ). In ventral view, opening of pygofer with midventral elongately rounded lobe (Fig 7B), attenuating distally to rounded apex. Gonostyli broad and cupped (in lateral view, Fig 7 C), expanded distally; dorsal margin near midlength bearing a rounded projection with a laterally directed sclerotized tooth (gonostyli distally 
Fig 5 Agoo argutiola sp. $\mathrm{n}$. (paratype), head and thorax: (A) face, frontal view; (B) head and thorax, dorsal view; (C) head and thorax, lateral view.

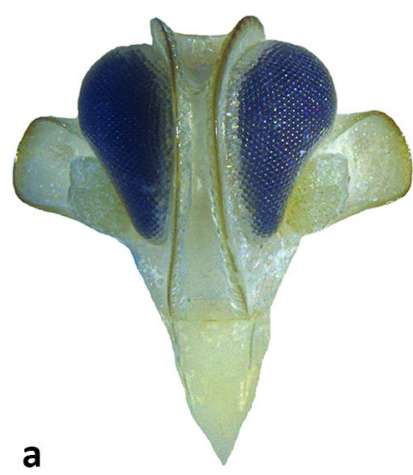

a

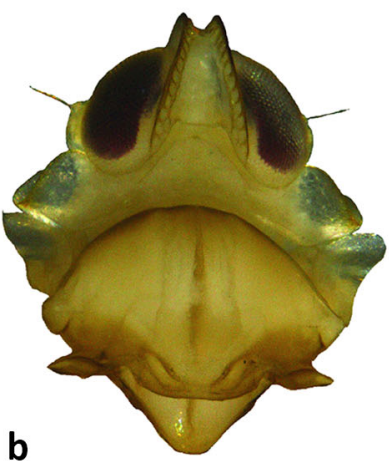

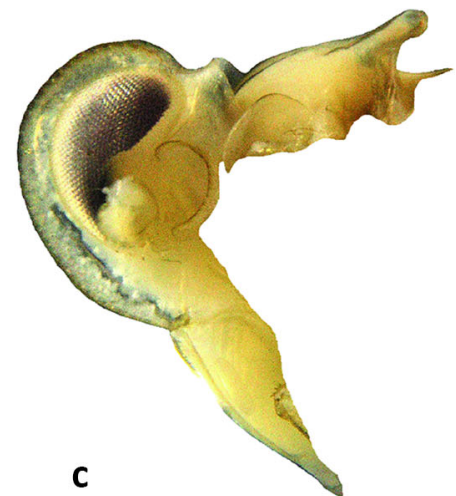

C expanded, giving the appearance of a notch after this projection). Gonostyli in ventral view (Fig $7 \mathrm{~B}$ ) with medially directed projection near midlength bearing two short sclerotized spines on inner margin, distal spine about twice as large as basal spine. Apodemes of gonostyli conspicuous, extending beyond pygofer into abdomen. Phallotheca stout (Fig 6D-F), approximately bilaterally symmetrical; shaft of phallotheca with elongate retrorse processes near apex (each with irregularly arranged serrations near midlength), one each side of large retrorse flagellum; flagellum with 2 pairs of elongate apical processes (apparently articulated, about equal-sized) arranged in transverse row (Figs 6D, E); and 1 elongate midventral process. Anal tube in lateral view roughly triangular, distally broadened, ventrally sinuate, caudal margin concave at anal column, ventrocaudal portion elongate (apically rounded) (Fig 7C). In dorsal view, anal tube notched on caudal aspect; anal column short, appearing quadrate.

Plant associations. Oil palm (Elaeis guineensis Jacq.), and coconut (Cocos nucifera L), both Arecaceae.

Distribution. Brazil (Roraima).
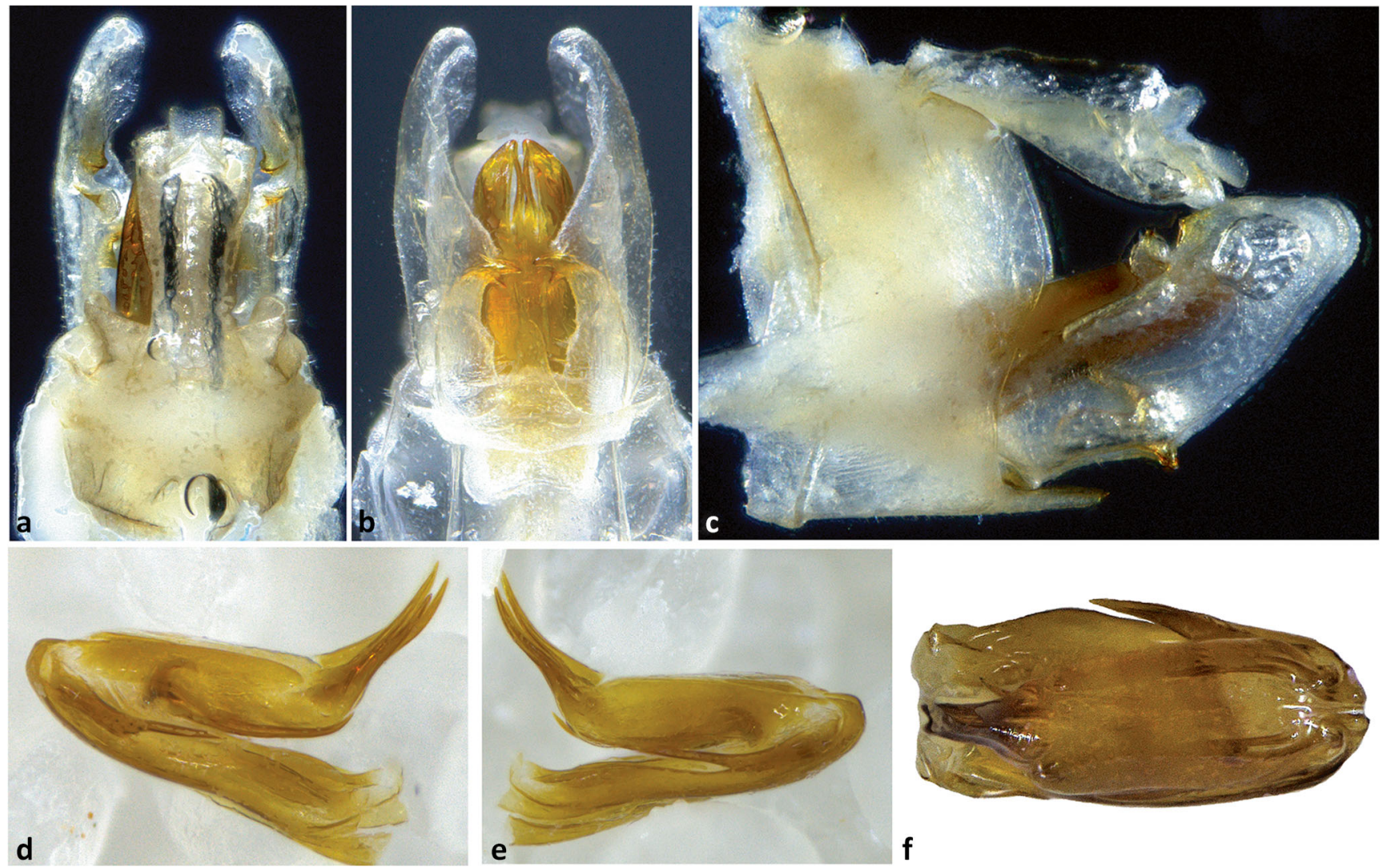

Fig 6 Agoo argutiola sp. n. (paratype): (A) terminalia, dorsal view; (B) terminalia, ventral view; (C) terminalia, lateral view; (D) extracted phallotheca, left lateral view; (E) phallotheca, right lateral view; (F) phallotheca, dorsal view (proximal portion to left). 

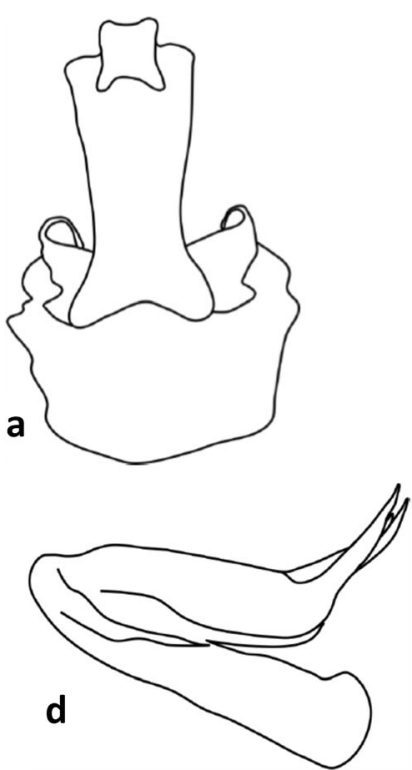

b
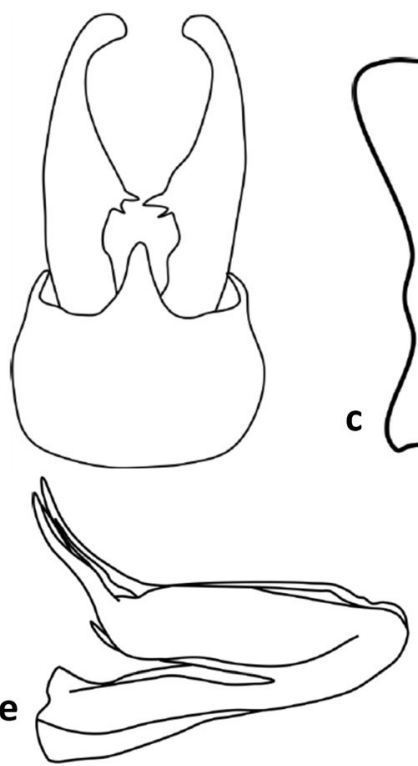

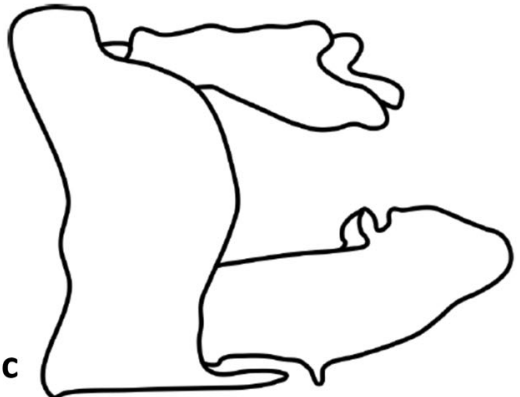

Fig 7 Line art for terminalia of Agoo argutiola sp. n. (paratype): (A) terminalia, dorsal view; (B) terminalia, ventral view; (C) terminalia, lateral view; (D) extracted phallotheca, left lateral view; (E) phallotheca, right lateral view; (F) phallotheca, dorsal view (proximal portion to left).
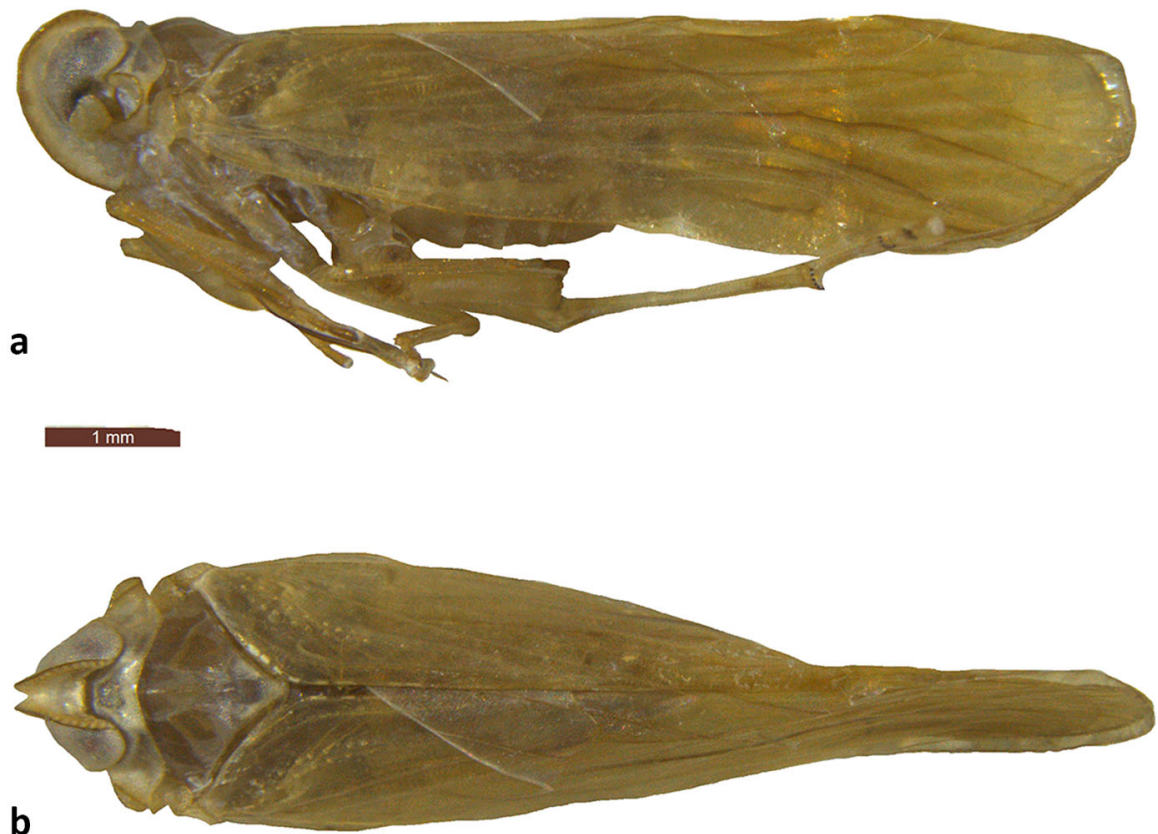

Fig 8 Agoo spina sp. n.

(holotype): (A) lateral view,

habitus; (B) dorsal view habitus;

(C) head and thorax, dorsal view;

(D) head and thorax, lateral view.
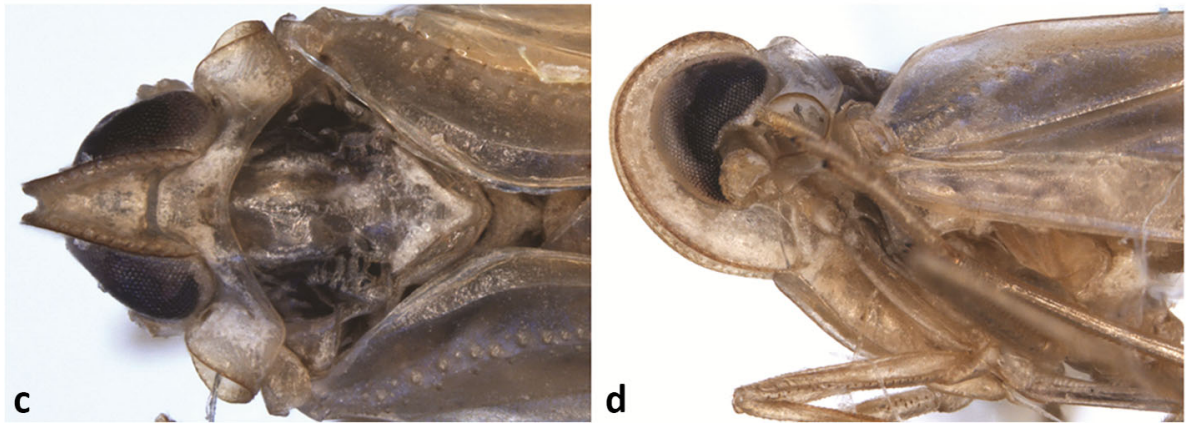
Fig 9 Agoo spina sp. $\mathrm{n}$. (paratype), head and thorax: (A) face, frontal view; (B) head and thorax, dorsal view; (C) head and thorax, lateral view.
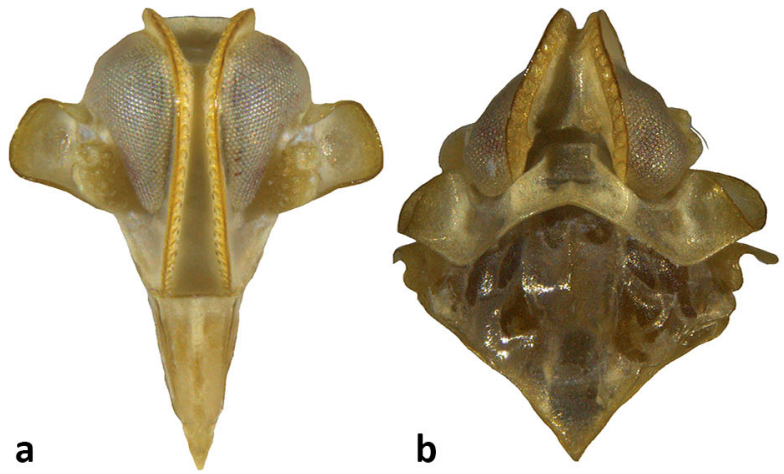

C

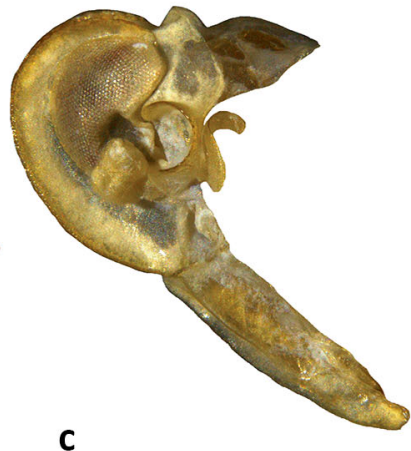

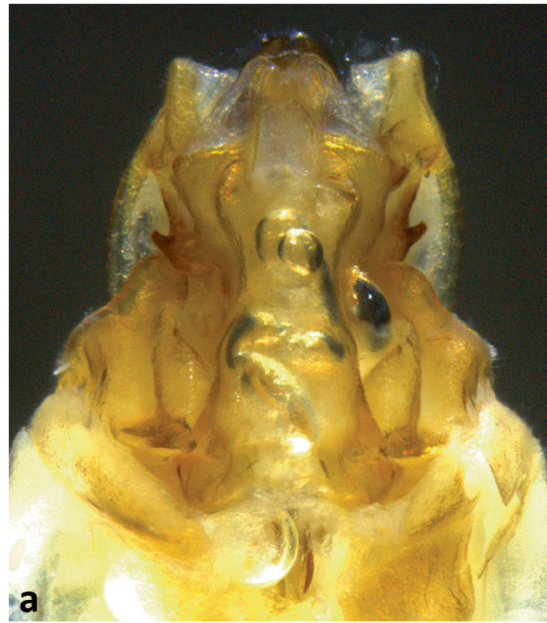
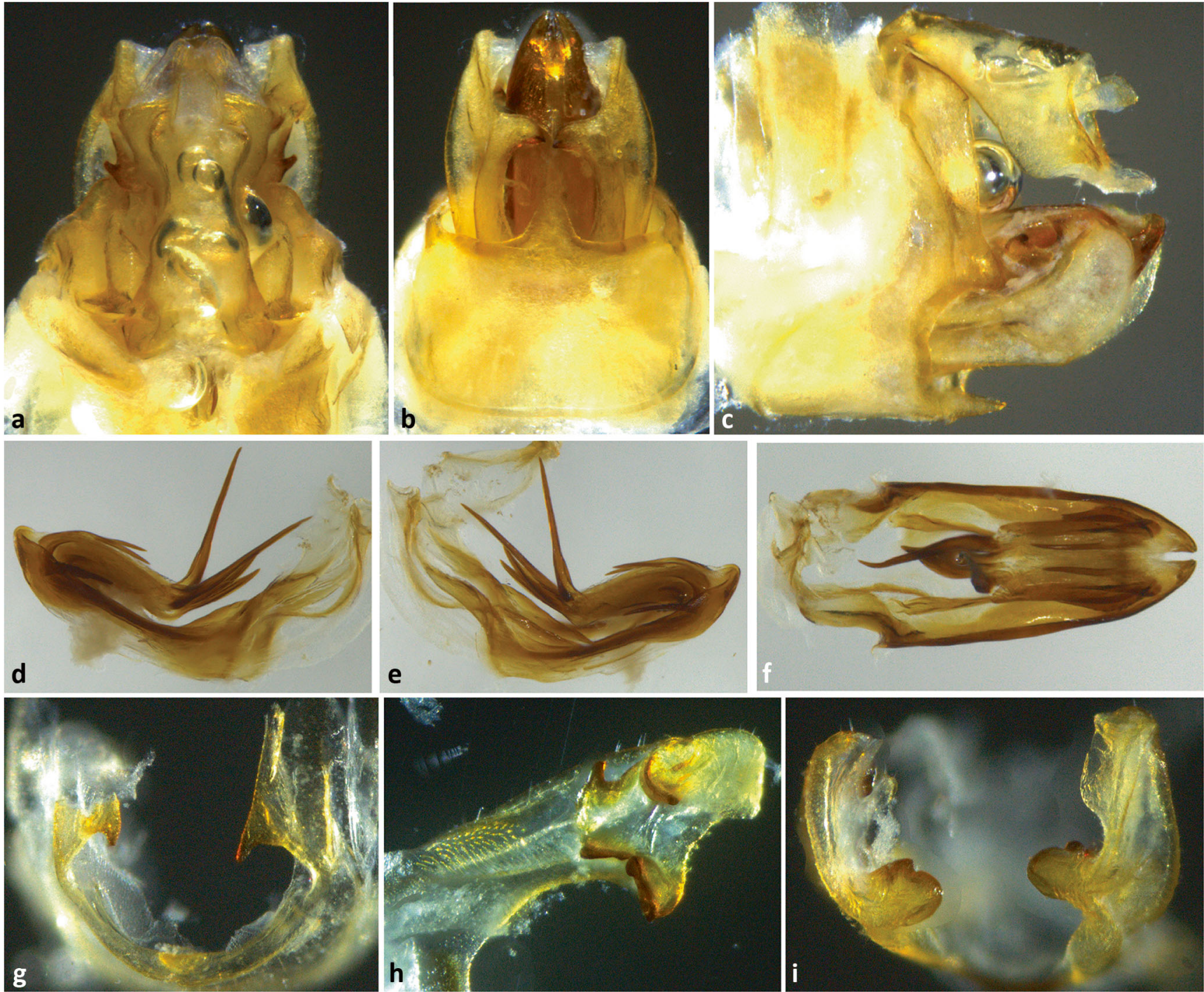

Fig 10 Terminalia of Agoo spina sp. n. (paratype): (A) Terminalia, dorsal view; (B) terminalia, ventral view; (C) terminalia, lateral view; (D) extracted phallotheca, left lateral view; (E) phallotheca, right lateral view; (F) phallotheca, dorsal view (proximal portion to left); (G) caudal view of pygofer showing projections on lateral margin of opening; $(\mathrm{H})$ detail of median lobe of gonostyli showing irregularly tri-lobed trailing margin; (I) apex of gonostyli, caudal view. 


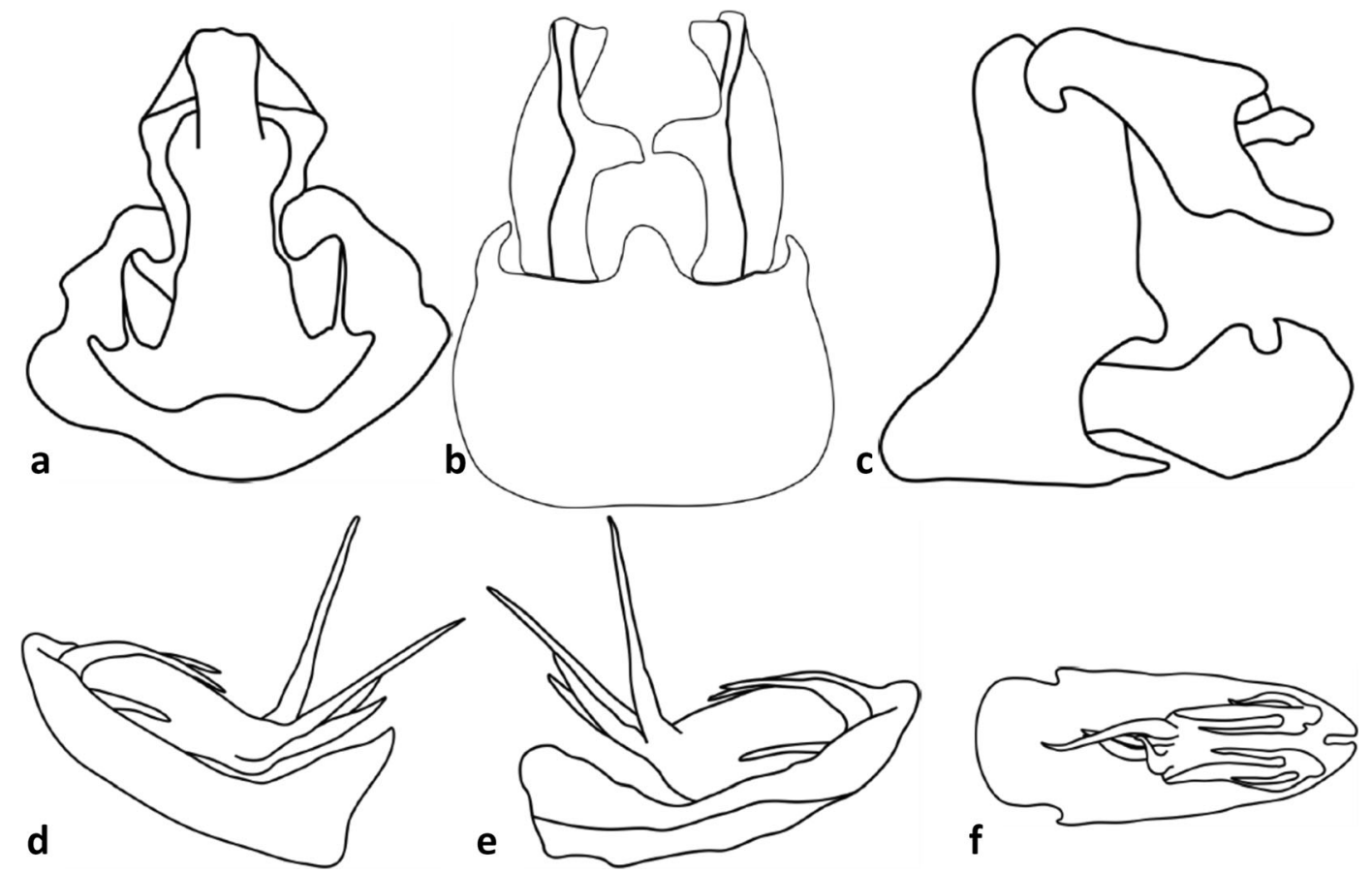

Fig 11 Line art of terminalia of Agoo spina sp. n. (paratype): (A) terminalia, dorsal view; (B) terminalia, ventral view; (C) terminalia, lateral view; (D) extracted phallotheca, left lateral view; (E) phallotheca, right lateral view; (F) phallotheca, dorsal view (proximal portion to left).

Etymology. The specific name argutiola is a Latin diminutive of argutia, meaning a piece of subtlety, a reference to some of the diagnostic features in Omolicna. The name is feminine in gender.

Material examined. HOLOTYPE male "22933 S 28 / (cig. Branca) / Bresil: Roraima / Nova Colina // 3.VIII.2016 / Elaeis guineensis / Dollet \& Fidelis Leg. // UDCC_TCN 00058471 [2d barcode]// HOLOTYPE / Agoo argutiola / Bahder \& Bartlett" (1 male, dissected, MPEG). PARATYPES, same data (2d barcode numbers: UDCC_TCN 00097147, UDCC_TCN 00097148) (2 males,
MPEG); same data, UDCC_TCN 00097146, 00 $366^{\prime} 48.7^{\prime \prime}$ $\mathrm{N}, 60^{\circ} 17^{\prime} 39.7^{\prime \prime} \mathrm{W}$, in alcohol, 2 females, UDCC); Roraima, Boa Vista, $2^{\circ} 47^{\prime} 02.6^{\prime \prime} \mathrm{N}, 60^{\circ} 45^{\prime} 12.5^{\prime \prime} \mathrm{W}$, coconut, 27-VII2016, Michel Dollet \& Elisangela Fidelis leg (1 male, UDCC); Roraima, São João da Baliza, $0^{\circ} 56$ '07.9"N $59^{\circ} 52^{\prime} 40.4 \mathrm{~W}$, coconut, 21-III-2017, Michel Dollet \& Elisangela Fidelis leg. (sample SJ4b, 1 male, UDCC); same, dated (20-21)-III-2017, coconut (an additional specimen from this locality appears to have different terminalia and is excluded from the paratype series).

Agoo spina Bahder \& Bartlett sp. $\mathrm{n}$.
Fig 12 Forewings (A) Agoo argutiola sp. n.; (B) Agoo spina sp. $\mathrm{n}$.
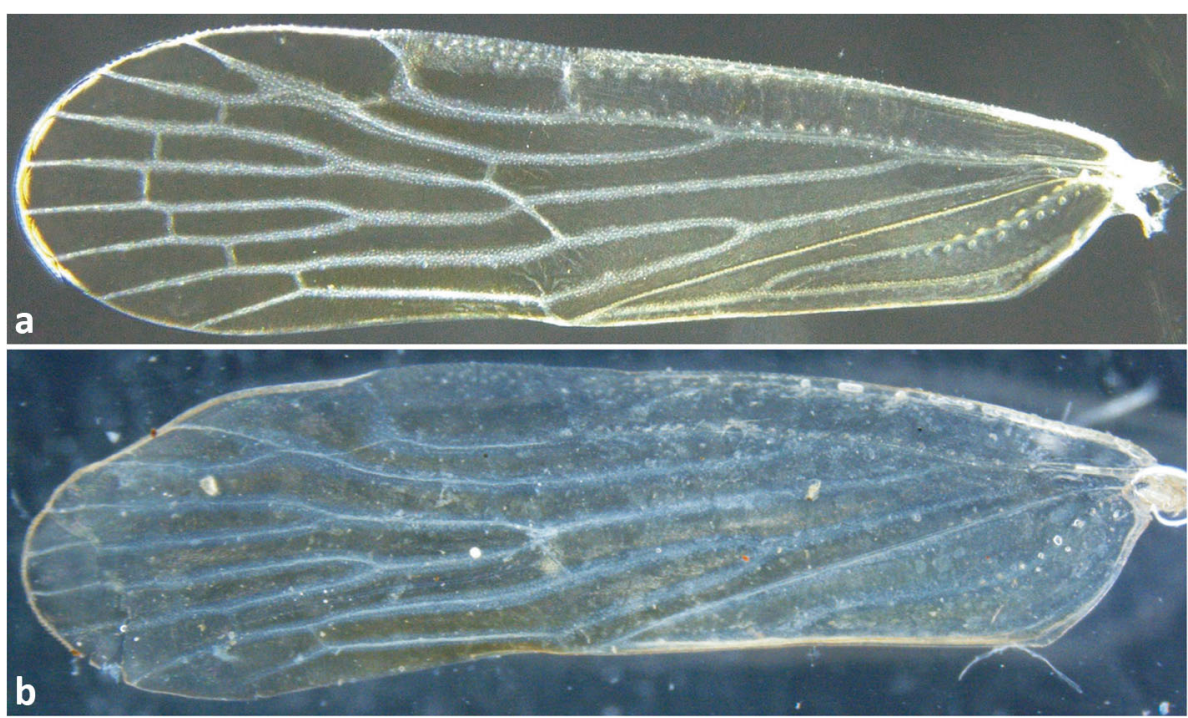
Fig 13 Forewing venation, line art: (A) Agoo argutiola sp. n.; (B) Agoo spina sp. $\mathrm{n}$.
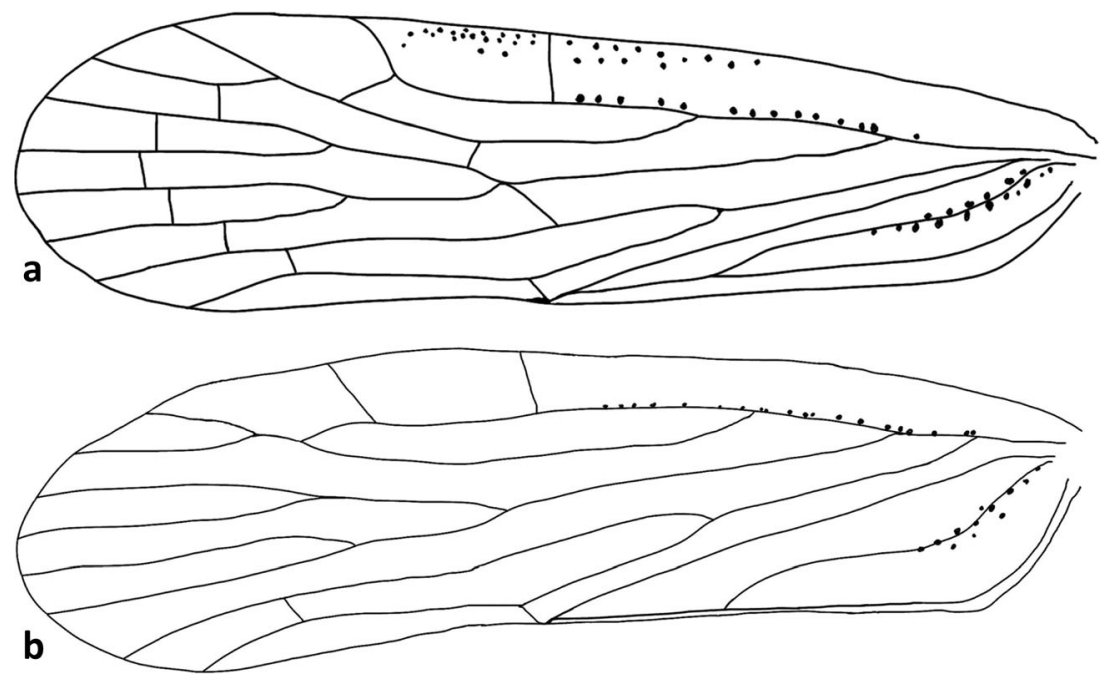

(Figs 8, 9, 10, 11, 12B, and 13B)

Type locality. Brazil, Sergipe, Itaporanga D’Ajuda.

Diagnosis. Male pygofer with median ventral process broad near base, attenuating distally to broadly rounded apex (lateral teeth lacking); lateral margins of pygofer opening with acuminate transversely projecting processes. Gonostyli in ventral view with acuminate medially directed lobe, trailing edge of lobe irregularly tri-lobed. Flagellum of aedeagus with pair of dorsal retrorse processes arising near junction with aedeagal shaft.

Description. Color. General body color is uniformly tan (Fig 8). Carinae on face darker. Mesonotum darker on lateral portions (pale medially). Forewings transparent (Fig 12B), veins pale; weakly infuscated with dark in basal third (except leading margin), faintly infuscated more distal.

Structure. Body length males (with wings): 6.89-6.95 mm $(n=2)$ with wings; females not available for study; body length (without wings): not available (dissected). Head: Anterior margin of head, in lateral view, smoothly rounded from posterior margin of vertex to frontoclypeal suture (Figs 8A, D and 9C). In dorsal view, vertex quadrately concave posteriorly between compound eyes, medially truncate (Fig 9B). Vertex disc medially deeply depressed between foliately carinate lateral margins (median carina absent); lateral margins most widely separated posteriorly, converging anteriorly to narrow fastigium; lateral keels of vertex bearing a row of (sensory?) pits. Transverse carina of fastigium absent. Vertex length (males): $0.31-0.32 \mathrm{~mm}$; width (hind margin) $0.33-0.34 \mathrm{~mm}$; vertex width (apical margin) $0.12-$ $0.14 \mathrm{~mm}$. Frons elongate, medially depressed (Fig 9A, median carina absent), lateral keels strongly foliate, bearing row of pits, continuous with vertex. Frons narrowest between compound eyes, broadening to frontoclypeal suture. Frons length (males): $0.85-0.87 \mathrm{~mm}$; frons width (narrowest, between eyes): 0.12-0.14; width (frontoclypeal margin): $0.33-0.34 \mathrm{~mm}$. Ocelli obsolete. Antennae stout, scape very short ( $0.05 \mathrm{~mm})$, pedicle rather rounded (almost mushroom-shaped, $0.25 \mathrm{~mm}$ ), bearing irregularly arranged sensillae, flagellum not evident (possibly broken). Clypeus elongate, broadest at frontoclypeal martin, narrowing distally to labrum; median carinae present, lateral carinae weakly carinae keeled, pits wanting. Clypeus length: 0.61-0.63 mm.

Thorax. Pronotum narrow (length at midline $0.21-$ $0.25 \mathrm{~mm}$ ), anterior margin following contours of posterior margin of head (Fig 9B); medially convex and truncate behind vertex, narrowed behind eyes. Posterior pronotal margin medially concave; median carina of pronotum very weak, lateral carinae distinct, reaching caudal margin; anterior keel following anterior margin of pronotum behind eye to antennal fossa in paradiscal field. In lateral view (Fig 9C), posterior margin of pronotum foliate, appearing inflected upward; lateral portion of paradiscal field forming strongly foliate fossa, enveloping posterior margin of antennae, and partially surrounding antennae both dorsally and ventrally. Mesonotum appearing slightly elevated in lateral view; in dorsal view with median and 2 lateral longitudinal carinae, reaching scutellum. Scutellum separated from scutum by inflection, dorsolateral angles of scutellum bearing lateral projections (may be hidden by forewings in repose). Mesonotum length at midline $0.68-0.77 \mathrm{~mm}$, width at tegulae $0.75-0.81 \mathrm{~mm}$.

Forewing (Figs $12 \mathrm{~B}$ and $13 \mathrm{~B}$ ) with a row of pits along basal $1 / 2$ of $\mathrm{ScP}+\mathrm{R}(+\mathrm{M})$ and basal half of postcubitus. Venation ScP+RA forked from RP in basal $1 / 3$ of wing. Fork of CuA and fusion of $P C u+1 A$ at nearly same level; SCP (unbranched) from RA at about wing midlength; RP 2branched; MP 4-branched; CuA 2-branched plus short branch near apex of clavus; claval apex at nearly wing midlength; A1 tracking wing margin (wing margin inflected 
to be obscured in lateral view of body); combined Pcu+1A reaching margin before apex of clavus.

Terminalia. Pygofer in lateral view widest near base (Fig 11C), proximal and distal margins irregularly sinuate, subparallel; proximal margin concave, distal convex with an acuminate transversely projecting process just below midlength (Fig 10G). Pygofer opening in ventral view bearing an elongate lobe, widest at base and attenuating distally to rounded apex. Gonostyli (in lateral view) broad (Fig 11C), distally expanded into rounded, cup-like structure; apex bluntly rounded; dorsal subapical region with pair of asymmetrical lobes, each bearing a large, the distal lobe with the tooth directed medially, the proximal lobe with tooth directed laterad; in ventral view (Fig 11B), each gonostylus bearing a large, triangular lobe directed dorsomedially, their dorsal surfaces sclerotized and irregularly lobed (Fig $10 \mathrm{H})$. Apodemes from gonostyli elongate and conspicuous projecting into abdomen beyond pygofer. Phallotheca stout (Fig 10D-F), nearly bilaterally symmetrical; shaft with small laterodorsal subbasal tooth on each side and elongate retrorse process arising at each side of flagellum base (these appearing partly serrulate in dorsal view); apex of shaft subtended by pair of cupped projections from ventral surface (giving appearance of apical notch in dorsal view); aedeagal flagellum strongly retrorse bearing 4 pairs of elongate processes, 1 dorsal pair near flagellar base, 1 pair on flagellar underside, arising near base and 2 apical pairs arranged in a roughly transverse row (lateral pair longer), appearing articulated at base (Fig 10D, E). Anal tube stout in lateral view broadly triangular, broadened caudally, dorsal margin straight to anal column, ventral margin sinuate, apex rounded; in dorsal view caudal margin apically concave anal column short (Fig 11C).

Plant associations. Coconut palm (Cocos nucifera), Arecaceae.

Distribution. Brazil (Sergipe).

Etymology. The species name is from the Latin term spina meaning thorn, a reference to the process on the lateral margins of the pygofer opening. The term is intended to be feminine in gender.

Material examined. HOLOTYPE male "Brazil, Sergipe / Itaporanga D'Ajuda / 22-Jul-17 / Coconut, sweeping net / Eliana Passos // UDCC_TCN 00097417 [2d barcode label]// Agoo argutiola / Bartlett \& Bahder" (dissected male, MPEG). PARATYPES: BRAZIL, Sergipe, Itaporanga D'Ajuda, Active germplasm bank of coconut; 19.V.2016; aspirated from Coconut, Eliana Passos, UDCC_TCN 00097419 (2d barcode label) (2 males, dissected, UDCC).

Remarks. Agoo spina sp. n. and Agoo argutiola sp. n. both differ from Agoo xavieri in the form of the flagellum of the phallotheca-both of the new species possess a terminal transverse row of 4 processes, whereas $A$. xavieri does not. Agoo spina and Agoo argutiola are quite similar except that the former possesses an acuminate medially directed lobe on the lateral margin of pygofer opening (lacking in $A$. argutiola) and possesses a pair of elongate retrorse processes on the dorsum of the flagellum (lacking in A. argutiola).

\section{Discussion}

In this work, we document eight species of planthoppers in the family Derbidae associated with coconut or oil palm in Brazil. Undoubtedly, there are other derbid species to be found associated with palms. Additional derbids not reported here were collected in Bonfim (East of Boa Vista), Boa Vista, Nova Colina, and Mucajai that remain to be investigated, including specimens similar to Omolicna and Cedusa. The presence and abundance of derbids on palms has been observed many times; for example, Howard (2001) lists 91 derbid species reported from palms, nearly doubling the number compiled by Lepesme (1947). Zelazny \& Pacumbaba (1982) report collecting 4978 derbid specimens representing 15 taxa from coconut palms in Luzon, Philippines. Wilson et al (1994) report $36 \%$ of the derbid plant association records compiled by them are from palms, and $63 \%$ of derbid species with host associations are reported from a single plant species. Available data in FLOW (Bourgoin 2020) indicate that $16.7 \%$ of published plant associations for Derbidae are Arecaceae, more than any other plant family (next are Poaceae and Sapindeceae at $11.4 \%$ each).

The nymphal stages of derbids are associated with moist organic debris (e.g., Wilson 1987a, Wilson et al 1994, Howard et $a / 2001$ ) and are assumed to feed on fungal hyphae (e.g., Wilson et al 1994, Bartlett et al 2014), and adults move to plants to feed and mate. It is possible that the association between palms and derbids (at least for some derbid species) has less to do with nutrition, and more to do with relationships between palms and derbid larval habitat, or plant structure or allelochemistry as they relate to mate-finding or substrate-born communication (Wilson 1987b).

While the association between some derbids and palms is evident from current survey efforts in Costa Rica (Bahder et al 2019, 2020a, b), the biological significance is not. Habitats where members of the genus Agoo have been sampled extensively and in great numbers have failed to identify non-palm host plants (Bahder, unpublished data). There has been no unequivocal evidence that derbids transmit palm pathogens, which remains a critical issue. Powell et al (2015) documented the presence of the 16SrIV-D phytoplasma in the newly discovered Omolicna joi; however, this was based on DNA extraction from the whole body of the insect. Detection of phytoplasma from whole-body extractions of 
insects has some use in vector studies because it allows for the identification of species that are in fact feeding on infected palms. However, positive reactions using this approach are highly susceptible to obtaining false positives. Screening for phytoplasmas is commonly done using the $16 \mathrm{~S}$ gene which is highly conserved and commonly results in the amplification of other species of bacteria from the insect gut or that it has acquired through feeding (Wally et al 2008). Another form of false positive is when the whole body is tested and true phytoplasma DNA is amplified but is residual phytoplasma passing through the gut. Residual pathogens can be detected in non-vectors (Cieniewicz et al 2018) so to understand if derbids do contribute to transmission of phytoplasmas, screening of salivary glands will need to be performed on specimens to assess if they are capable of transmitting the phytoplasma in question.

That two of the species we found had not been previously described is a testament both to the incompleteness of past survey work of palm-associated planthoppers, and the taxonomic challenges associated with the derbid tribe Cenchreini. Among the Cenchreini, there has been no quantitative phylogenetic treatments at any level and the diagnostic morphological differences among genera are incompletely defined. Diagnostic molecular work to supplement species descriptions and test generic placement (e.g., to confirm placement of the new species described here in the genus Agoo) and monophyly are needed both to amend basic science (i.e., taxonomy, especially to define species, investigate intraspecific variation and confirm associations of males, females and nymphs) but also to provide additional diagnostic and applied tools.

Nomenclature ZooBank registration can be found at: urn:Isid:zoobank.org:pub:B6D0575E-1C39-4825-8DA50879A1FF6BB5; Agoo argutiola Bahder and Bartlett urn:Isid: zoobank.org:act:CA623FE3-A7CA-432A-83B4-DE3145CEBEF2; Agoo spina Bahder and Bartlett urn:Isid:zoobank.org:act: 194C7BDB-B2D8-446B-B96C-C913553C25D7.

Acknowledgments We thank Empresa Brasileira de Pesquisa Agropecuária (Embrapa) and Conselho Nacional de Desenvolvimento Científico e Tecnológico (CNPq, National Council for Scientific and Technological Development, Ministry of Science and Technolog) for the funding and assistance, in particular the CNPq grant "Pesquisador Visitante Especial" (Visiting Scientist) to Michel Dollet for 2015-2017. Additional funding was from CIBA/Cirad (Consortium international en biologie avancée) to Michel Dollet. We thank Gunvi Lindberg of the Swedish Royal Museum of Natural History in Stockholm for photographs of type material. We thank Mick Webb of The Natural History Museum, London for photographs of the type material of Cenanges spectralis Fennah. We thank Paige Cummins (University of Delaware) for specimen photography and line art, and Thierry Bourgoin (Muséum National d'Histoire Naturelle) for directing us to plant associations data in FLOW.

Author Contributions Conceptualization: Michel Dollet, Leandro Diniz, Elisangela Fidelis; data curation: Elisangela Fidelis, Michel Dollet,
Flaviana Da Silva, Eliana Dos Passos; funding acquisition: Leandro Diniz, Michel Dollet; investigation: Elisangela Fidelis, Eliana Passos, Flaviana Da Silva, Charles Bartlett, Brian Bahder, Henri Pierre Aberlenc, Daniel Schurt, Michel Dollet; project administration: Leandro Diniz, Elisangela Fidelis; resources: Leandro Diniz, Elisangela Fidelis; supervision: Michel Dollet, Leandro Diniz, Elisangela Fidelis; visualization: Michel Dollet, Charles Bartlett, Brian Bahder, Elisangela Fidelis; writing-original draft: Charles Bartlett, Michel Dollet; writing-review and editing: Charles Bartlett, Michel Dollet, Brian Bahder, Elisangela Fidelis. All authors read and approved the final manuscript.

Open Access This article is licensed under a Creative Commons Attribution 4.0 International License, which permits use, sharing, adaptation, distribution and reproduction in any medium or format, as long as you give appropriate credit to the original author(s) and the source, provide a link to the Creative Commons licence, and indicate if changes were made. The images or other third party material in this article are included in the article's Creative Commons licence, unless indicated otherwise in a credit line to the material. If material is not included in the article's Creative Commons licence and your intended use is not permitted by statutory regulation or exceeds the permitted use, you will need to obtain permission directly from the copyright holder. To view a copy of this licence, visit http://creativecommons.org/licenses/ by/4.0/.

\section{References}

Arthropod Easy Capture (2013) An arthropod specific, specimen level data capture application, Version: 1.34. https://sourceforge.net/ projects/arthropodeasy. Accessed 3 July 2019

Bahder BW, Bartlett CR, Barrantes EA, Echavarria MAZ, Humphries AR, Helmick EE, Ascunce MS, Goss EM (2019) A new species of Omolicna (Hemiptera: Auchenorrhyncha: Fulgoroidea: Derbidae) from coconut palm in Costa Rica and new country records for Omolicna brunnea and Omolicna triata. Zootaxa 4577:501-514

Bahder BW, Bartlett CR, Helmick EE, Barrantes EA, Echavarria MAZ, Goss EM, Ascunce MS (2020a) Revised status of Omolicna subgenus Agoo (Hemiptera: Auchenorrhyncha: Fulgoroidea: Derbidae) with a new species from Costa Rica and new country records. Zootaxa 4718: 521-535

Bahder BW, Zumbado Echavarria MA, Barrantes EA, Bartlett CR, Helmick $\mathrm{EE}$, Kunz G, Ascunce MS (2020b) A new species of planthopper in the genus Agoo (Hemiptera: Fulgoroidea: Derbidae) from coquito palms (Astrocaryum alatum) in Costa Rica. Zootaxa (in press)

Balick MJ (1979) Amazonian oil palms of promise: a survey. Econ Bot 33: $11-28$

Bartlett CR, O'Brien LB, Wilson SW (2014) A review of the planthoppers (Hemiptera: Fulgoroidea) of the United States. Mem Am Entomol Soc 50:1-287

Bourgoin T (1988) A new interpretation of the homologies of the Hemiptera male genitalia illustrated by the Tettigometridae (Hemiptera, Fulgoromorpha). In: Vidano C, Arzone A (eds) Proceedings of the 6th Auchenorrhyncha meeting. Consiglio Nazionale delle Ricerche, IPRA, Rome, pp 113-120

Bourgoin T (2020) FLOW (Fulgoromorpha lists on the web): a world knowledge base dedicated to Fulgoromorpha. Version 8 (updated 24 April 2020). http://hemiptera-databases.org/flow/ Accessed 30 April 2020

Bourgoin T, Huang J (1990) Morphologie comparée des genitalia m les des Trypetimorphini et remarques phylogénétiques (Hemiptera: Fulgoromorpha: Tropiduchidae). Ann Soc Entomol Fr (Nouvelle Serie) 26:555-564 
Bourgoin T, Wang RR, Asche M, Hoch H, Soulier-Perkins A, Stroinski A, Yap S, Szwedo J (2015) From micropterism to hyperpterism: recognition strategy and standardized homology-driven terminology of the forewing venation patterns in planthoppers (Hemiptera: Fulgoromorpha). Zoomorphology 134:63-77

Brondizio ES (2011) Forest resources, family networks and the municipal disconnect: examining recurrent underdevelopment in the Amazon estuary. In: Pinedo-Vasquez M, Ruffino ML, Padoch C, Brondízio ES (eds) The Amazon Várzea: the decade past and the decade ahead. Springer, Basel, pp 207-229

Brown SE, Been BO, McLaughlin WA (2006) Detection and variability of the lethal yellowing group (16Sr IV) phytoplasmas in the Cedusa sp. (Hemiptera: Auchenorrhyncha: Derbidae) in Jamaica. Ann Appl Biol 149:3-62

Caldwell JS (1944) The tribe Cenchreini with special references to the Cenchrea complex (Homoptera: Derbidae). Bull Brooklyn Entomol Soc 39:99-110

Cieniewicz EJ, Pethybridge SJ, Loeb G, Perry KK, Fuchs M (2018) Insights into the ecology of Grapevine red blotch virus in a diseased vineyard. Phytopathology 108:94-102

Clair D, Larrue J, Boudon-Padieu E (2001) Evaluation of vectoring ability of phytoplasmas by Metcalfa pruinosa say (Homoptera: Flatidae) recently introduced in Europe. International Organization for Biological and Integrated Control of Noxious Animals and Plants, West Palearctic Regional Section (IOBC wprs). Bulletin 24:195-197

Dollet M, Talamani V (2018) Fitoplasmas associados às Síndromes do Tipo Amarelecimento Letal das Palmeiras. In: Fidelis E, Lohmann TR, Silva ML, Parizzi P, Laranjeira FF (eds) Priorização de pragas quarentenárias ausentes no Brasil. Embrapa, Brasília, pp 313-350

Dollet M, Quaicoe R, Pilet F (2009) Review of coconut "lethal yellowing" type diseases diversity, variability and diagnosis. OCL 16:97-101

Eden-Green SJ (1997) History and world distribution of lethal yellowinglike diseases of palms. In: Eden-Green SJ, Ofori F (eds). Proceedings of an International workshop on lethal yellowing diseases of coconut, Natural Resources Institute Chatham, pp 9-25

Emeljanov AF (1992) Two new tribes, a new genus and a new species of the family Derbidae (Homoptera: Fulgoroidea). Vestnik Zool 4:19-23

Emeljanov AF (1996) On the system and phylogeny of the family Derbidae (Homoptera, Cicadina). Entomol Rev 75:70-100

Emeljanov AF (2008) New species of the genus Peltonotellus Puton (Homoptera, Caliscelidae) from Kazakhstan, Middle and Central Asia. Tethys Entomol Res 16:5-12

FAO (2020) FAOSTAT food and agriculture data. http://www.fao.org/ faostat/en/\#home/. Accessed 03 Mar 2020

Fennah RG (1945) The Fulgoroidea, or lanternflies, of Trinidad and adjacent parts of South America. Proc U S Natl Mus 95(3184):411-520

Fennah RG (1952) On the generic classification of Derbidae (Fulgoroidea), with descriptions of new neotropical species. Trans $\mathrm{R}$ Entomol Soc Lond 103:109-170

Fennah RG (1961) Le Parc National de Niokolo-Koba. XXXIII Homoptera Fulgoroidea. Mém l'Instiut Fr l'Afr Noire 62:305-320

Flynn JE, Kramer JP (1983) Taxonomic study of the planthopper genus Cedusa in the Americas (Homoptera: Fulgoroidea). Entomography 2: $121-260$

Fontes HR, Wanderley M (2006) Situação atual e perspectivas para a cultura do coqueiro no Brasil. Embrapa Tabuleiros Costeiros, Aracaju, p 16 (Documentos, 94) http://wwwcpatcembrapabr/publicacoes_ 2006/doc-94pdf/. Accessed 03 Feb 2020

Halbert SE, Wilson SW, Bextine B, Youngblood SB (2014) Potential planthopper vectors of palm phytoplasmas in Florida with a description of a new species of the genus Omolicna (Hemiptera: Fulgoroidea). Fla Entomol 97:90-97

Howard FW (2001) Sap-feeders on palms. In: Howard FW, Moore D, Giblin-Davis RM, Abad RG (eds) . Insects on palms CABI Publishing, Wallingford, pp 109-232
Howard FW, Weissling TJ, O'Brien LB (2001) The larval habitat of Cedusa inflata (Hemiptera: Auchenorrhyncha: Derbidae) and its relationship with adult distribution on palms Florida. Entomologist 84(1):119-122

IBGE (2018) Censo Agropecuário 2017. https://sidra.ibge.gov.br/ pesquisa/censoagropecuario/censoagropecuario-2017/. Accessed 06 Feb 2020

Kahn F (1991) Palms as key swamp forest resources in Amazonia. Forest Ecol Manage 38:133-142

Kramer JP (1986) Supplement to a taxonomic study of the planthopper genus Cedusa in the Americas (Homoptera: Fulgoroidea: Derbidae). Entomography 4:245-314

Lee HS, Wilson SW (2010) First report of the Nearctic flatid planthopper Metcalfa pruinosa (Say) in the Republic of Korea (Hemiptera: Fulgoroidea). Entomol News 121(5):506-513

Lepesme P (1947) Les insectes des Palmiers. Lechevalier, Paris, p 904

Martins CR, Jesus Júnior LA (2014) Produção e Comercialização de Coco no Brasil Frente ao Comércio Internacional: Panorama 2014. Embrapa Tabuleiros Costeiros, Aracaju, p 51 (Documentos 184) https://ainfo. cnptia.embrapa.br/digital/bitstream/item/122994/1/Producaoecomercializacao-Doc-184.pdf/. Accessed 03 Feb 2020

McCoy RE, Howard FW, Tsai JH, Donselman HM, Thomas DL, Basham HG, Atilano RA, Eskafi FM, Britt LL, Collins ME (1983) Lethal yellowing of palms. Agricultural Experiment Stations Bulletin 834. University of Florida, Gainesville

McGrath P (2002) Red alert to lethal yellow. New agriculturist On line. http://www.new-ag.info/o2-3/develop/dev05.html

Metcalf ZP (1938) The Fulgorina of Barro Colorado and other parts of Panama. Bull Museum Comp Zool Harv Coll 82:277-423

Metcalf ZP (1945) Fulgoroidea (Homoptera) of Kartabo, Bartica District, British Guiana. Zoologica Scientific Contributions of the New York Zoological Society 30(14):125-143

Mpunami A, Tymon A, Jones P, Dickinson MJ (2000) Identification of potential vectors of the coconut lethal disease phytoplasma. Plant Pathol 49:355-361

Mtiiz-Miret N, Vamos R, Hiraoka M, Montagnini F, Mendelsohn R (1996) The economic value of managing the açai palm (Euterpe oleracea Mart.) in the floodplains of the Amazon estuary, Pará, Brazil. Forest Ecol and Manage 87:163-173

Muir FAG (1913) On some new species of leafhoppers Part II Derbidae. Bull Hawaiian Sugar Plant Assoc Exp Stat Div Entomol 12:28-92

Muir FAG (1918) Notes on the Derbidae in the British Museum collection-II Derbidae. Entomol Mon Mag 54:228-243

O'Brien LB (1982) Two Neotropical derbid genera with observations on wing rolling (Fulgoroidea: Homoptera). Fla Entomol 65:306-321

O'Brien LB (1987) Corrections and additions to Metcalf's "the Fulgorina of Barro Colorado and other parts of Panama" (Homoptera: Fulgoroidea). Ann Entomol Soc Am 80:379-390

Philippe R, Pokou Nkansah J, Fabre S, Quaicoe R, Pilet F, Dollet M (2007) Search for the vector of Cape Saint Paul Wilt (coconut lethal yellowing) in Ghana. Bull Insectol 60:179-180

Philippe R, Reignard S, Descamps S, Nkansah-Poku J, Pilet F, Fabre S, Dollet M (2009) Study on the transmission of coconut lethal yellowing in Ghana. OCL 16:102-106

Powell CM, Hail D, Potocnjak J, Hanson JD, Halbert SH, Bextine BR (2015) Bacterial community composition of three candidate insect vectors of palm phytoplasma (Texas Phoenix Palm Decline and lethal yellowing). Curr Microbiol 70(2):240-245

Rajan P (2013) Transmission of coconut root (wilt) disease through planthopper, Proutista moesta Westwood (Homoptera: Derbidae). Pest Manag Hort Ecosyst 17:1-5

Rocca MM (2013) Palm diseases in central America. Phytopathol 103: S2.177

Rodrigues JVC, Segarra AE, Ramirez A (2010) Nested-PCR assays detect phytoplasma in Cedusa caribbensis Caldwell \& Martorell (Hemiptera: Auchennorhyncha: Derbidae) in Puerto Rico. In: Proceedings of the Potential Invasive Pests Workshop, Miami, Florida, pp 59 
Schuh RT (2012) Integrating specimen databases and revisionary systematics. ZooKeys 209:255-267

Schuh RT, Hewson-Smith S, Ascher JS (2010) Specimen databases: a case study in entomology using web-based software. Am Entomol 56:206216

Spinola M (1839) Essai sur les Fulgorelles, sous-tribu de la tribu des Cicadaires, ordre des Rhyngotes. Ann Soc Entomol Fr 8:133-337

Sullivan M, Harrison N (2013) CPHST Pest Datasheet for 'Candidatus Phytoplasma palmae' and related strains. USDA-APHIS-PPQ-CPHST. Revised June, 2014. http://download.ceris.purdue.edu/file/1910

Szwedo J (2006) First fossil record of Cedusini in the Eocene Baltic amber with notes on the tribe (Hemiptera: Fulgoromorpha: Derbidae). Russian Entomol J 15:327-333

Tunçer B, Schroeder P (2017) Sambazon: creating environmental and social values through marketing the açai berry. In: Ursula Tischner, St $\varnothing E$, Kjærnes $U$, Tukker A (eds) Sustainable agro-forestry practices in the Brazilian Amazon. System innovation for sustainability 3: case studies in sustainable consumption and production. Food and Agriculture. Routledge, London, pp 160-175

Wally O, El Hadrami A, Khadhair AH, Adam LR, Shinners-Carnelley T, Elliott $B$, Daayf $F$ (2008) DNA sequencing reveals false positives during the detection of aster yellows phytoplasmas in leafhoppers. Sci Hortic 116:130-137

Weintraub PG, Beanland L (2006) Insect vectors of phytoplasmas. Annu Rev Entomol 51:91-111
Wilson MR (1987a) African Derbidae (Homoptera, Fulgoroidea): taxonomic notes with descriptions of new species collected mainly from coconut. J Nat Hist 21(3):567-595

Wilson MR (1987b) The Auchenorrhyncha (Homoptera) associated with palms. In: Wilson MR, Nault LR (eds) Proceedings of the 2nd International Workshop on Leafhoppers and Planthoppers of Economic Importance. CAB International Institute of Entomology, Provo, pp 327-342

Wilson SW (2005) Keys to the families of Fulgoromorpha with emphasis on planthoppers of potential economic importance in the southeastern United States (Hemiptera: Auchenorrhyncha). Fla Entomol 88: 464-481

Wilson SW, Mitter C, Denno RF, Wilson MR (1994) Evolutionary patterns of host plant use by delphacid planthoppers and their relatives. In: Denno RF, Perfect TJ (eds) Planthoppers: their ecology and management. Chapman and Hall, New York, pp 7-45

Zelazny B, Pacumbaba E (1982) Phytophagous insects associated with cadang-cadang infected and healthy coconut palms in South-Eastern Luzon, Philippines. Ecol Entomol 7:113-120

Publisher's Note Springer Nature remains neutral with regard to jurisdictional claims in published maps and institutional affiliations. 